\title{
Tubulin-Binding 3,5-Bis(styryl)pyrazoles as Lead Compounds for the Treatment of Castration-Resistant Prostate Cancer ${ }^{\mathrm{s}}$
}

\author{
Vivian W.Y. Liao, ${ }^{3}$ Anuradha Kumari, ${ }^{3}$ (D) Rajeshwar Narlawar, Soma Vignarajan, \\ (1)David E. Hibbs, Dulal Panda, and Paul W. Groundwater
}

\begin{abstract}
Sydney Pharmacy School, Faculty of Medicine and Health (V.W.Y.L., R.N., D.E.H., P.W.G.) and Charles Perkins Centre (S.V.), The University of Sydney, Sydney, New South Wales, Australia; and Department of Biosciences and Bioengineering, Indian Institute of Technology Bombay, Mumbai, India (A.K., D.P.)
\end{abstract}

Received October 17, 2019; accepted March 24, 2020

\section{ABSTRACT}

The microtubule-binding taxanes, docetaxel and cabazitaxel, are administered intravenously for the treatment of castrationresistant prostate cancer (CRPC) as the oral administration of these drugs is largely hampered by their low and highly variable bioavailabilities. Using a simple, rapid, and environmentally friendly microwave-assisted protocol, we have synthesized a number of 3,5-bis(styryl)pyrazoles $\mathbf{2 a - I , ~ t h u s ~ a l l o w i n g ~ f o r ~}$ their screening for antiproliferative activity in the androgenindependent PC3 prostate cancer cell line. Surprisingly, two of these structurally simple 3,5-bis(styryl)pyrazoles (2a and 2l) had concentrations which gave $50 \%$ of the maximal inhibition of cell proliferation $\left(\mathrm{Gl}_{50}\right)$ in the low micromolar range in the PC3 cell line and were thus selected for extensive further biologic evaluation (apoptosis and cell cycle analysis, and effects on tubulin and microtubules). Our findings from these studies show that 3,5-bis[(1E)-2(2,6-dichlorophenyl)ethenyl]-1H-pyrazole 2l 1) caused significant effects on the cell cycle in PC3 cells, with the vast majority of treated cells in the $\mathrm{G}_{2} / \mathrm{M}$ phase $(89 \%)$; 2 ) induces cell death in PC3 cells even after the removal of the compound; 3 ) binds to tubulin [dissociation constant $\left(\mathrm{K}_{\mathrm{d}}\right)$
$0.4 \pm 0.1 \mu \mathrm{M}]$ and inhibits tubulin polymerization in vitro; 4) had no effect upon the polymerization of the bacterial cell division protein FtsZ (a homolog of tubulin); 5) is competitive with paclitaxel for binding to tubulin but not with vinblastine, crocin, or colchicine; and 6) leads to microtubule depolymerization in PC3 cells. Taken together, these results suggest that 3,5-bis(styryl)pyrazoles warrant further investigation as lead compounds for the treatment of CRPC.

\section{SIGNIFICANCE STATEMENT}

The taxanes are important components of prostate cancer chemotherapy regimens, but their oral administration is hampered by very low and highly variable oral bioavailabilities resulting from their poor absorption, poor solubility, high firstpass metabolism, and efficient efflux by P-glycoprotein. New chemical entities for the treatment of prostate cancer are thus required, and we report here the synthesis and investigation of the mechanism of action of some bis(styryl)pyrazoles, demonstrating their potential as lead compounds for the treatment of prostate cancer.

\section{Introduction}

Globally, prostate cancer is the second most common male cancer in terms of incidence and fifth in terms of mortality, with over 300,000 men dying from the disease every year (Todd et al., 2018). Tumor growth in the early stages of prostate cancer is androgen-dependent, so the typical treatment of early metastatic prostate cancer is androgen deprivation therapy with a gonadotropin-releasing hormone analog such as leuprolide, often in combination with an antiandrogen such as flutamide (Crawford et al., 1989; Garnick, 1997; Taplin and Balk, 2004).

This work was partially supported by a grant from the Department of Biotechnology [BT/PR14618/BRB/10/1418/2015], Government of India, and partly by a JC Bose fellowship [JCB/2019/000016], Department of Science and Technology, Government of India, to D.P.

${ }^{3}$ V.W.Y.L. and A.K. contributed equally to this work.

https://doi.org/10.1124/mol.119.118539.

S This article has supplemental material available at molpharm. aspetjournals.org.
As the disease progresses, however, molecular and cellular changes occur so that cancer becomes androgen-independent/ hormone refractory (termed castration-resistant prostate cancer [CRPC]) and unresponsive to current hormone therapy (Feldman and Feldman, 2001; Todd et al., 2018). This form of prostate cancer is aggressive, highly metastatic, and associated with poor prognosis (mean survival time of 18-24 months) (Abouelfadel and Crawford, 2008), and there is no effective treatment (Karantanos et al., 2013).

Paclitaxel has been used in the treatment of prostate cancer, and the semisynthetic taxanes, docetaxel and cabazitaxel, are administered intravenously for the treatment of CRPC. The oral administration of these drugs is hampered by their low and highly variable bioavailabilities (Torne et al., 2010), which are due to their poor absorption (a result of their poor solubilities); efficient efflux by P-glycoprotein, which is abundant in the gastrointestinal tract; and high first-pass metabolism by CYP450s, CYP2C8 and 3A4.

ABBREVIATIONS: AUC, area under the curve; CRPC, castration-resistant prostate cancer; $\mathrm{Gl}_{50}$, concentrations which gave $50 \%$ of the maximal inhibition of cell proliferation; HPLC, high-pressure liquid chromatography; $\mathrm{K}_{d}$, dissociation constant; MTT, 3-(4,5-dimethyl-2-thiazolyl)-2,5diphenyl-2H-tetrazolium bromide; OD, optical density; PDB, Protein Data Bank; PI, propidium iodide; PIPES, 1,4-piperazinediethanesulfonic acid. 
We report here the discovery of a 3,5-bis(styryl)pyrazole analog 21 that induces cell death in PC3 cells (Pulukuri et al., 2005; Schmitt et al., 2014) even after the removal of the compound. The compound binds to tubulin $\left(\mathrm{K}_{\mathrm{d}} 0.4 \pm 0.1 \mu \mathrm{M}\right)$ and inhibits tubulin polymerization in vitro (with no effect upon the polymerization of the bacterial homolog Streptococcus pneumoniae FtsZ (spn FtsZ) or on the activity of alkaline phosphatase). Pyrazole 21 is competitive with paclitaxel for binding to tubulin (but not with vinblastine, crocin, or colchicine), and treatment with pyrazole 21 results in microtubule depolymerization in PC3 cells, suggesting the further investigation of these 3,5-bis(styryl)pyrazoles as lead compounds for the treatment of CRPC.

\section{Materials and Methods}

General Synthetic Chemistry Procedures. The 3,5-bis(styryl) pyrazoles 2a-l were synthesized from the curcuminoids 1 (Supplemental Methods) using a CEM Discover SP microwave synthesis system. The spectroscopic and analytical data for pyrazoles $2 \mathbf{a}$ (Amolins et al., 2009; Mayadevi et al., 2012), $2 \mathbf{b}$ (Amolins et al., 2009), and $2 \mathbf{k}$ (Luo et al., 2013) were identical to that reported previously. Melting points were determined on a Stuart Scientific SMP10 apparatus. Infrared spectra were obtained on a FTIR-8400S Shimadzu system using $\mathrm{NaCl}$ plates, and values are recorded as wave numbers $\left(\mathrm{cm}^{-1}\right) .{ }^{1} \mathrm{H}$ and ${ }^{13} \mathrm{C}$ NMR spectra were recorded at 400 and $100 \mathrm{MHz}$, respectively, on a Varian 400-MR magnetic resonance spectrometer, with chemical shifts $(\delta)$ reported in parts per million (ppm). Spectra were acquired in solutions of deuterated solvents, and the residual solvent peaks were used as internal references: $7.24 \mathrm{ppm}$ (deuterochloroform, $\mathrm{CDCl}_{3}$ ), $2.50 \mathrm{ppm}$ (DMSO- $d_{6}$ ), $2.05 \mathrm{ppm}$ (acetone- $d_{6}$ ), and $3.31 \mathrm{ppm}\left(\right.$ methanol- $d_{4}$ ). Lowresolution electrospray ionization mass spectrometry was performed on a TSQ Quantum Access Max LCMS/MS (Thomas R Watson Mass Spectrometry Laboratory, Sydney Pharmacy School, The University of Sydney), and high-resolution mass spectroscopy was performed on a Bruker 7T Fourier transform ion cyclotron resonance mass spectrometer (Mass Spectrometry Unit, School of Chemistry, The University of Sydney). Elemental analysis was performed on a Thermo Flash 2000 Elemental Analyzer (Campbell Microanalytical Laboratory, University of Otago, New Zealand). All reagents were commercially available and purchased from Sigma Aldrich (Castle Hill, Sydney, Australia) and Alfa Aesar (VWR, Australia). Solvents were purchased from Chem-Supply (Australia) and were used as received. Flash column chromatography was performed using Grace Davison (LC604 40-63 $\mu \mathrm{m}$ ) Davisil chromatographic silica media. Thin-layer chromatography was performed using Grace Davidson Reveleris, aluminum-backed thin-layer chromatography plates (UV254).

General Experimental Procedure for the Synthesis of Pyrazoles 2a-l. Pyrazole derivatives 2a-l were synthesized using a modification of the method of Mayadevi et al. (2012). Curcuminoids 1 $(1.0 \mathrm{mmol})$ were dissolved in $N, N$-dimethylformamide (DMF) $(1 \mathrm{ml})$. Acetic acid $(1 \mathrm{ml})$ and hydrazine monohydrate $(0.2 \mathrm{ml})$ were added to the solution in a microwave synthesizer tube. The mixture was placed in the microwave reactor and heated at $80^{\circ} \mathrm{C}$ for 5 minutes with rapid stirring. The reaction was cooled then added dropwise to stirred water $(100 \mathrm{ml})$. The solid was collected by filtration, purified by flash chromatography using a gradient mobile phase of ethyl acetate and hexane (1:4 to 1:1), and then recrystallized from ethanol. Spectroscopic and analytical data for the pyrazoles are provided in the Supplemental Methods.

General Experimental Procedure for the Degradation Studies. HiPerSolv CHROMANORM liquid chromatography-mass spectrometry grade acetonitrile and methanol were purchased from VWR International. High-performance liquid chromatography (HPLC) grade glacial acetic acid was purchased from Fisher Scientific, UK. Ultrapure water was obtained with an SG Ultra Clear water system. The chromatographic separation was performed on an Aquacil $\mathrm{C}_{18}$ column $(2.1 \times 100 \mathrm{~mm}, 5 \mu \mathrm{m}$ particle size; Thermo Scientific).

An orbital mixter incubator (Ratek Instruments, Australia) was used for the degradation study at $37^{\circ} \mathrm{C}$ and $200 \mathrm{rpm}$. The HPLC analysis was carried out on a Shimadzu ultrafast liquid chromatography prominence system, consisting of a DGU-20A5R degassing unit, an LC-20AD pump, a SIL-20AHT autosampler, a SPD-M20A photodiode array detector, and a personal computer with LabSolutions CS software for data acquisition and processing.

Chromatographic Conditions and Preparation of Standards. The chromatographic method was adapted from Jayaprakasha et al. (2002). The mobile phase consisted of varying gradients of acetonitrile (A) and $2 \%$ aq. acetic acid solution (B), with a flow rate of $0.75 \mathrm{ml} / \mathrm{min}$. The total run time was 25 minutes, the last 10 minutes equilibrating the column for the next run. The wavelength of detection was the $\lambda_{\max }$ of each compound $(\mathbf{2 a} ; 325 \mathrm{~nm} ; 21300 \mathrm{~nm})$. The injection volume was $10 \mu \mathrm{l}$. Table 1 summarizes the chromatographic conditions used for each of the compounds.

Methanolic standard stock solutions $(1 \mathrm{mg} / \mathrm{ml})$ were prepared for each of the analyzed compounds. The stock solutions were diluted in methanol to obtain concentrations of $0.01,0.02,0.03,0.04,0.05$, and $0.06 \mathrm{mg} / \mathrm{ml}$. For less concentrated standard samples of $\mathbf{2 a}$ and $\mathbf{2 l}$, a $1 \mu \mathrm{g} / \mathrm{ml}$ standard stock was prepared from the $1 \mathrm{mg} / \mathrm{ml}$ stock, and the stock solutions were diluted in methanol to obtain 100, 50,20,10, 5 , and $2 \mathrm{ng} / \mathrm{ml}$ solutions. All standards were freshly prepared from the stock solutions on the day of analysis. The stock solutions were stored at $-20^{\circ} \mathrm{C}$. The area under the curve (AUC) versus the concentration of each compound standards was plotted and fitted with linear regression analysis using GraphPad Prism to calculate the slope, intercept, and correlation coefficient and thus determine the linearity of the standard curve (Supplemental Tables 1 and 2). For reproducibility, the experiment was repeated three times, on three separate days, with freshly prepared standard solutions for each compound.

Degradation Study. The degradation study was carried out according to the method outlined by Tønnesen and Karlsen (1985). Compounds 2a and $2 \mathbf{l}$ were dissolved in methanol $(1 \mathrm{mg} / \mathrm{ml}$ concentration). The methanolic solution $(100 \mu \mathrm{l})$ of the compounds was then added to prewarmed PBS $\left(900 \mu l, 37^{\circ} \mathrm{C}\right)$ and placed in the orbital incubator. At time points of 1, 2, 4, 8, 12, 24, 48, and 72 hours, $100 \mu \mathrm{l}$ of the solution was removed and extracted twice with ethyl acetate $(2 \times 200 \mu \mathrm{l})$. The ethyl acetate extracts were combined and evaporated, and the residues were redissolved in methanol $(200 \mu \mathrm{l})$ for HPLC analysis. Ten microliters of the original methanolic solutions were removed, evaporated, and redissolved in methanol $(200 \mu \mathrm{l})$, and this was taken as $t=0$. The AUC is the total absorbance of the compound at that given concentration and was used for quantification. The degradation profiles of each of the compounds are expressed as percentages of compounds remaining in PBS at the sampled time, with the AUC at $t=0$ taken as $100 \%$.

The detection and quantification limits for analogs $\mathbf{2 a}$ and $\mathbf{2 1}$ were calculated according to the method outlined in the guidelines of International Committee on Harmonization (2005) (https:// www.ich.org/fileadmin/Public_Web_Site/ICH_Products/Guidelines/ Quality/Q2_R1/Step4/Q2_R1__Guideline.pdf) using the following formulae:

$$
\begin{gathered}
\text { Detection limit }=33 \sigma / \text { slope } \\
\text { Quantification limit }=10 \sigma / \text { slope, }
\end{gathered}
$$

TABLE 1

HPLC conditions for each of the compounds analyzed

\begin{tabular}{lccc}
\hline Compound & $\begin{array}{c}\text { 0-15 min } \\
\text { (linear gradient) }\end{array}$ & $\begin{array}{c}\text { 15-20 min } \\
\text { (linear gradient) }\end{array}$ & $\begin{array}{c}\text { 20-25 min (isocratic } \\
\text { re-equilibration) }\end{array}$ \\
\hline \multicolumn{4}{c}{ Solvent gradient \% A } \\
2a & $30-70$ & $70-30$ & 30 \\
2l & $60-80$ & $80-60$ & 60 \\
\hline
\end{tabular}

A, acetonitrile; B, $2 \%$ aq. acetic acid solution. 
<smiles>[R]c1c([R])c([R])c(/C=C/C(=O)CC(=O)/C=C/c2c([R])c([R])c([R])c([R])c2[R])c([R])c1[R]</smiles>

$1 \mathrm{a}-\mathrm{I}$

$$
\begin{aligned}
& \text { a } \mathrm{R}^{2}=\mathrm{R}^{5}=\mathrm{R}^{6}=\mathrm{H}, \mathrm{R}^{3}=\mathrm{OMe}, \mathrm{R}^{4}=\mathrm{OH} \\
& \text { b } R^{2}=R^{5}=R^{6}=H, R^{3}=R^{4}=O M e \\
& \text { c } \mathrm{R}^{2}=\mathrm{R}^{5}=\mathrm{R}^{6}=\mathrm{H}, \mathrm{R}^{3}=\mathrm{OEt}, \mathrm{R}^{4}=\mathrm{OH} \\
& d^{2} R^{2}=R^{5}=R^{6}=H, R^{3}=O H, R^{4}=O M e \\
& \text { e } R^{2}=R^{5}=R^{6}=H, R^{3}=\text { OMe, } R^{4}=\text { OEt } \\
& f R^{2}=R^{3}=R^{5}=R^{6}=H, R^{4}=M e
\end{aligned}
$$<smiles>[R]c1c([R])c([R])c(/C=C/c2cc(/C=C/c3c([R])c([R])c([R])c([R])c3[R])[nH]n2)c([R])c1[R]</smiles>

$$
\begin{aligned}
& \text { g } R^{2}=\text { OMe, } R^{3}=R^{4}=R^{5}=R^{6}=H \\
& \text { h } R^{2}=R^{4}=R^{5}=R^{6}=H, R^{3}=O M e \\
& \text { i R } R^{2}=R^{3}=R^{5}=R^{6}=H, R^{4}=O M e \\
& \text { j } R^{2}=R^{4}=R^{5}=R^{6}=H, R^{3}=O H \\
& \text { k R } R^{2}=R^{3}=R^{5}=R^{6}=H, R^{4}=O H \\
& \text { I R } R^{2}=R^{6}=C l, R^{3}=R^{4}=R^{5}=H
\end{aligned}
$$

Scheme 1. Synthesis of 3,5-bis(styryl) pyrazoles 2a-l. Reagents and conditions: (a) $\mathrm{NH}_{2} \mathrm{NH}_{2} \bullet \mathrm{H}_{2} \mathrm{O}, \mathrm{AcOH}, N, N$-dimethylformamide (DMF), microwave, $80^{\circ} \mathrm{C}, 5$ minutes. For detailed experimental protocols and spectroscopic information, see Supplemental Methods. where $\sigma$ is the S.D. of errors in regression of the standard curve generated upon linear regression fitting of the average values of three standard curves $(n=3)$.

The detection and quantification limits for $\mathbf{2 a}$ and $\mathbf{2 l}$ were verified by injecting multiple samples $(n=6)$ at the concentrations of the detection and quantification limits. The accuracy is expressed as the percentage of the S.D. divided by mean values of the six AUC values determined from the injected samples.

General Experimental Procedure for the In Vitro Testing. RPMI 1640 medium, PBS, trypsin/EDTA 10× solution, and 3-(4,5dimethyl-2-thiazolyl)-2,5-diphenyl-2H-tetrazolium bromide (MTT) were purchased from Sigma Aldrich. Fetal bovine serum (FBS) of Australian origin was purchased from Bovogen. PC3 cells were purchased from American Type Culture Collection (Manasses, VA; CRL-1435). Muse Count \& Viability Assay Kit, Muse Annexin V \& Dead Cell Assay kit, and Muse Cell Cycle Assay Kit were purchased from Millipore, Australia. A CLARIOstar microplate reader was used to measure the absorbance of MTT formazan at $540 \mathrm{~nm}$. A Muse Cell Analyzer (Merck, Millipore) was used to conduct the annexin $\mathrm{V}$ apoptosis and cell cycle analysis assays.

Antiproliferative Assay. PC3 cells were grown in RPMI 1640 supplemented with $10 \%$ FBS to $\sim 70-80 \%$ confluency before seeding. Antiproliferative activity was determined by the MTT colorimetric assay (Mosmann, 1983). The MTT stock solution (12 mM) was prepared by dissolving 3-(4,5-dimethylthiazol-2-yl)-2,5-diphenyltetrazolium bromide in PBS $(5 \mathrm{mg} / \mathrm{ml})$ filtered through a $0.2 \mu \mathrm{m}$ syringe filter.

The pyrazoles and methotrexate were dissolved in DMSO to make a $200 \mathrm{mM}$ stock. PC3 cells were seeded in 96-well plates at 3000 cells per well and incubated for 24 hours. The DMSO stock solutions were diluted in 10\% FBS supplemented RPMI 1640 media; six concentrations of each of the test compounds were added to wells (in triplicate) with the final DMSO concentration of less than $0.1 \%$ in each well. DMSO $(0.1 \%)$ in RPMI 1640 medium was also prepared and used as a vehicle control for each plate and represents $100 \%$ growth in this assay. The plates were then incubated for 72 hours $\left(\mathrm{T}_{72}\right)$.

After 72 hours, the medium was removed from each well and was replaced with $10 \%$ MTT stock solution in serum and phenol red-free RPMI 1640 medium (100 $\mu \mathrm{l} /$ well). The plates were then incubated for 3 hours at $37^{\circ} \mathrm{C}$ before removing the medium and replacing it with DMSO $(50 \mu \mathrm{l} /$ well). After mixing, the plates were placed in the microplate reader, and the absorbance was determined. A control plate was prepared in the same way as above and read 24 hours $\left(\mathrm{T}_{0}\right)$ after seeding. The experiment was repeated at least three times on three separate days to give $n=3$.

The percentage of inhibition of cell growth was then calculated using the following formula:

$$
\% \text { Growth inhibition }=100-\left(\left(\frac{A b s\left(T_{72}\right)-A b s\left(T_{0}\right)}{A b s(D M S O)-A b s\left(T_{0}\right)}\right) \times 100\right) .
$$

GraphPad Prism was used to determine the $\mathrm{GI}_{50}$ values using a nonlinear regression fit after first transforming concentrations to log scale values. All results were representative of three independent experiments conducted on three separate days.

Annexin V/Propidium Iodide Apoptosis Assay. PC3 cells were seeded in six-well plates at cell densities of 100,000 cells per well and incubated for 24 hours. The pyrazoles $\mathbf{2 a}$ and $\mathbf{2 l}$ were added to the wells at their $\mathrm{GI}_{50}$ concentration. DMSO (0.1\%) in RPMI medium was used as a vehicle control. The cells were incubated for 72 hours; then they were trypsinized, centrifuged, stained with the Muse Annexin V/Dead Cell kit according to manufacturer's instructions, and then analyzed using, Muse Cell Analyzer. The experiment was conducted in duplicate, with data acquisition of 4000 events, and the experiment was repeated three times on three separate days to give $n=3$.

A set of experiments was performed following the same procedure as above, but after 72 hours of drug treatment, the medium containing the pyrazoles was removed and replaced with fresh medium, and the cells were incubated for a further 72 hours. Cells were then trypsinized, stained with the Muse Annexin V/Dead Cell kit, and analyzed using the Muse Cell Analyzer. The experiment was conducted in duplicate, with data acquisition of 4000 events, and the experiment was repeated three times on three separate days to give $n=3$.

Cell Cycle Analysis. PC3 cells were treated in the same way as in the apoptosis assay except, after trypsinization, cells were counted, centrifuged, and fixed with cold ethanol solution $70 \%(\mathrm{v} / \mathrm{v})$ at $1 \times 10^{6}$ cells $/ \mathrm{ml}$. The cells were left to fix overnight at $-20^{\circ} \mathrm{C}$, then centrifuged, stained with the Muse Cell Cycle kit according to the manufacturer's instructions, and then analyzed using the Muse Cell Analyzer. The experiment was conducted in duplicate with data acquisition of 5000 events, and the experiment was repeated at least four times on four separate days to give $n=4$.

\section{TABLE 2}

$\mathrm{GI}_{50}$ values of 3,5-bis(styryl)pyrazoles $\mathbf{2 a - 1}$ in PC3 cells ${ }^{a}$

\begin{tabular}{lc}
\hline Compound & $\mathrm{GI}_{50}$ \\
\hline & $\mu \mathrm{M}$ \\
Methotrexate & $0.012 \pm 0.008$ \\
$\mathbf{2 a}$ & $0.85 \pm 0.34$ \\
$\mathbf{2 b}$ & $39.8 \pm 7.8$ \\
$\mathbf{2 c}$ & $3.4 \pm 0.1$ \\
$\mathbf{2 d}$ & $77.8 \pm 6.7$ \\
$\mathbf{2 e}$ & $69.3 \pm 9.4$ \\
$\mathbf{2 f}$ & $>500^{b}$ \\
$\mathbf{2 g}$ & $4.1 \pm 0.14$ \\
$\mathbf{2 h}$ & $26.9 \pm 1.7$ \\
$\mathbf{2 i}$ & $39.8 \pm 7.8$ \\
$\mathbf{2 j}$ & $24.2 \pm 0.5$ \\
$\mathbf{2}$ & $28.9 \pm 2.5$ \\
$\mathbf{2}$ & $2.21 \pm 0.33$ \\
\hline
\end{tabular}

${ }^{a}$ Data represent the mean \pm S.D. of three independent replicates $(n=3)$.

${ }^{b}$ Compound showed no growth inhibitory activity in PC3 cells at the highest tested concentration $(500 \mu \mathrm{M})$. 


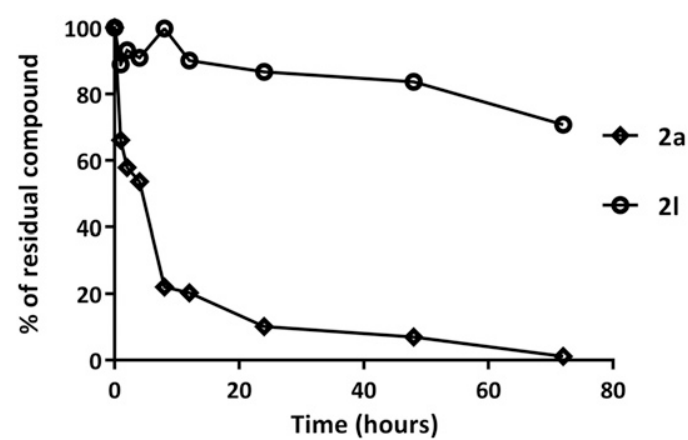

Fig. 1. Representative degradation profiles of pyrazoles $\mathbf{2 a}$ and $2 \mathbf{l}$ in PBS ( $\mathrm{pH} 7.4$ ) at $37^{\circ} \mathrm{C}$ in darkness over a period of 72 hours. Residual concentrations of each compound are expressed as percentages with respect to the concentration at time zero $(t=0,100 \%)$.

Experimental Procedure for the Tubulin and Microtubule Studies. The determination of the effects of the pyrazoles on the assembly kinetics of tubulin in vitro, the $\mathrm{K}_{\mathrm{d}}$ for the binding of the analogs to tubulin, and effect on microtubules in cells were performed as described previously (Panda et al., 2005).

Tubulin Purification. Tubulin was isolated from goat brain by two cycles of polymerization, and depolymerization as described previously (Panda et al., 2005).

Light Scattering. Tubulin $(12 \mu \mathrm{M})$ was incubated with different concentrations of $\mathbf{2 a}$ and $\mathbf{2 l}$ in PEM [50 mM 1,4-piperazinediethanesulfonic acid (PIPES), $1 \mathrm{mM}$ EGTA, and $3 \mathrm{mM} \mathrm{MgCl}{ }_{2}$ ] buffer, $\mathrm{pH}$ 6.8, on ice for 10 minutes. After 10 minutes of incubation, $10 \%$ DMSO and $1 \mathrm{mM}$ GTP was added to the reaction mixture, and polymerization was monitored at $37^{\circ} \mathrm{C}$ in a spectrophotometer, Spectramax M2 $2^{\mathrm{e}}$, at 350 $\mathrm{nm}$ for 30 minutes. The experiment was repeated three times, and the percentage inhibition of tubulin polymerization was calculated. The $\mathrm{IC}_{50}$ of polymerization was determined by fitting the data in doseresponse inhibition curve in the GraphPad Prism Software.

Sedimentation Assay. Tubulin $(12 \mu \mathrm{M})$ was polymerized at $37^{\circ} \mathrm{C}$ for 30 minutes in the presence and the absence of $\mathbf{2 a}$ and $\mathbf{2 1}$ as in light scattering. After 30 minutes, the polymerized microtubules were pelleted by centrifuging it at $33,000 \mathrm{~g}, 30^{\circ} \mathrm{C}$ for 30 minutes. The supernatant was separated, and the amount of polymerized microtubules was calculated by loading the supernatant and pellet on the SDS-PAGE gel followed by intensity quantification of bands by ImageJ or by quantifying the supernatant protein concentration by Bradford's assay.

Determination of Dissociation Constant. Tubulin $(2 \mu \mathrm{M})$ was incubated with and without different concentrations of $2 \mathbf{a}$ or 21 in
$25 \mathrm{mM}$ PIPES buffer $\mathrm{pH} 6.8$ for 10 minutes at room temperature. After incubation, the spectra of tryptophan emission were recorded in a spectrofluorometer (FP-6500; JASCO, Tokyo, Japan) by exciting the sample at $295 \mathrm{~nm}$ and recording the spectra. The fluorescence intensity at $\lambda_{\max }$ was noted, and it was fitted in the following equation in GraphPad Prism software to determine the $\mathrm{K}_{\mathrm{d}}$ :

$$
\Delta \mathrm{F}=\Delta F \max \times \frac{\left(\left[P_{0}\right]+\left[L_{0}\right]+K_{d}\right)-\sqrt{\left(\left[P_{0}\right]+\left[L_{0}\right]+K_{d}\right)^{2}-4\left[P_{0}\right]\left[L_{0}\right]}}{2\left[P_{0}\right]},
$$

where $\Delta \mathrm{F}_{\max }$ is the highest fluorescence intensity, $\mathrm{P}_{0}$ is the concentration of protein, and $\mathrm{L}_{0}$ is the concentration of $\mathbf{2 a}$ or $\mathbf{2 l}$.

Determination of Tubulin Binding Site of Pyrazole 21. Competitive inhibition with colchicine: tubulin $(5 \mu \mathrm{M})$ was incubated without or with 10 and $20 \mu \mathrm{M}$ of $2 \mathbf{l}$ on ice for 10 minutes in $25 \mathrm{mM}$ PIPES buffer $\mathrm{pH} 6.8$ and then incubated with $10 \mu \mathrm{M}$ colchicine for 45 minutes at $37^{\circ} \mathrm{C}$. The fluorescence spectra $(370-500 \mathrm{~nm})$ were monitored using a fluorescence spectrophotometer (FP-6500; JASCO) with excitation of the samples at $340 \mathrm{~nm}$.

Competitive Inhibition with Vinblastine and Crocin. First, we examined whether $2 \mathbf{l}$ could inhibit the binding of vinblastine to tubulin using BODIPY-FL-Vinblastine, a fluorescent analog of vinblastine (Lin and Chen, 2013). Tubulin $(3 \mu \mathrm{M})$ was incubated with 200 $\mathrm{nM}$ of BODIPY-FL-vinblastine (V12390; Thermo Scientific) on ice for 10 minutes in $25 \mathrm{mM}$ PIPES buffer $\mathrm{pH}$ 6.8. The reaction mixture was then incubated without or with 1 and $5 \mu \mathrm{M}$ of $2 \mathbf{l}$ for 10 minutes on ice. The change in fluorescence of BODIPY-FL-Vinblastine was observed in a spectrofluorometer (FP-6500; JASCO) by exciting at $488 \mathrm{~nm}$ and taking emission spectra from 498 to $540 \mathrm{~nm}$

Recently, it has been reported that vinblastine and crocin share their binding sites on tubulin (Hire et al.; 2017; Sawant et al., 2019). Therefore, we examined whether $\mathbf{2 l}$ could inhibit the binding of crocin to tubulin. Crocin $(5 \mu \mathrm{M})$ was incubated with $10 \mu \mathrm{M}$ tubulin for 10 minutes on ice in PEM buffer $\mathrm{pH}$ 6.8. The reaction mixture was then incubated with $10 \mu \mathrm{M} \mathbf{2 l}$ for 10 minutes on ice and then change in optical density (OD) from 410 to $500 \mathrm{~nm}$ was observed in a spectrophotometer (V-730; JASCO).

Docking of 21 with Tubulin. The structure of 21 was drawn in PubChem Sketcher (V2.4) and the Protein Data Bank (PDB) coordinates of 21 were generated in PRODRG server (Schüttelkopf and van Aalten, 2004). The Autodock Vina tool was used for docking of $2 \mathbf{l}$ on tubulin (Trott and Olson, 2010) as described previously (Rane et al., 2017; Hura et al., 2018). The crystal structure of tubulin (PDB identifier 5LYJ) was used for docking $2 \mathbf{l}$ with tubulin. The coordinates of all other proteins and molecules (tubulin-tyrosine ligase, CA-4, glycerol, stathmin, etc.) in 5LYJ, except one $\alpha$ and one $\beta$ subunit of
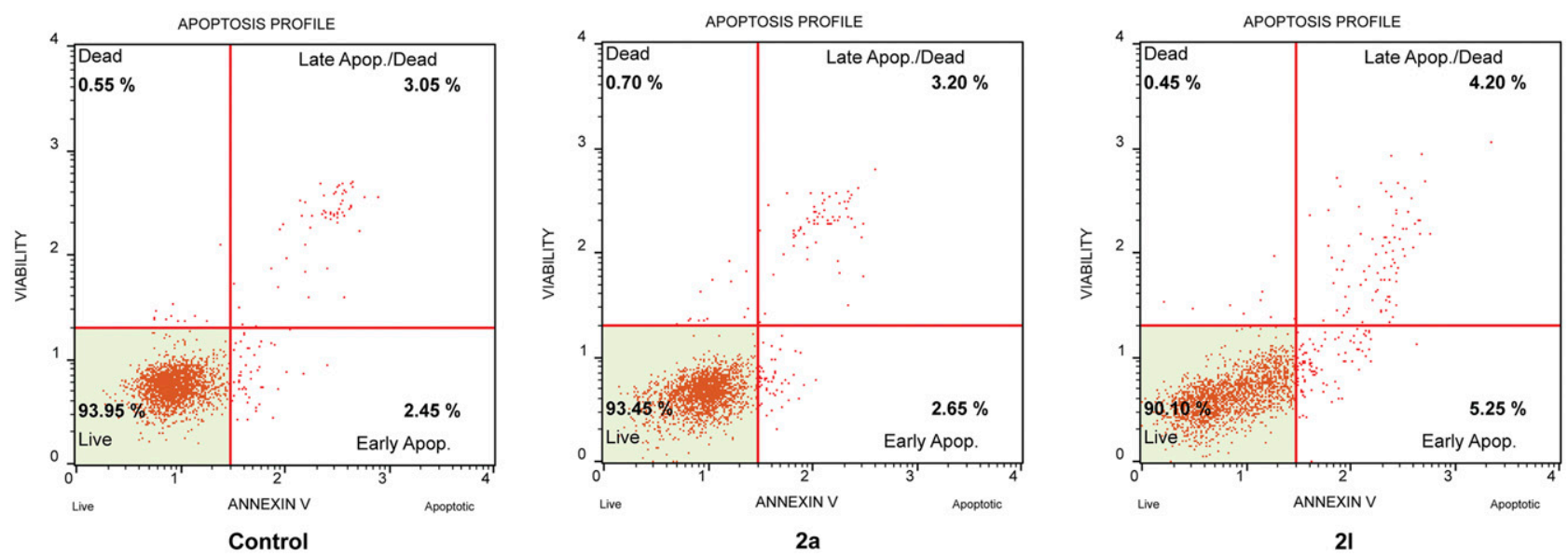

Fig. 2. Representative dot plots from the annexin V/PI apoptosis assay of PC3 cells treated with the $\mathrm{GI}_{50}$ concentrations of $\mathbf{2 a}$ and $\mathbf{2 1}$ for 72 hours. DMSO $(0.01 \%)$ was used as the vehicle control. 
A

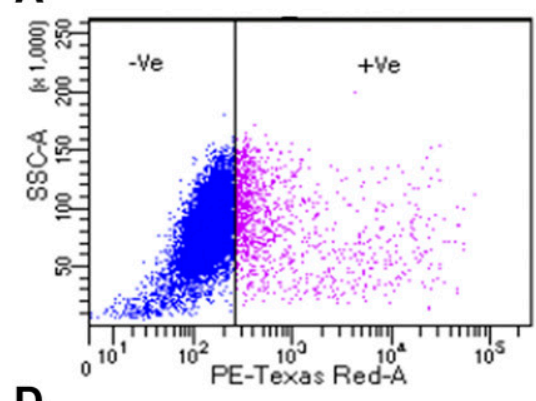

D

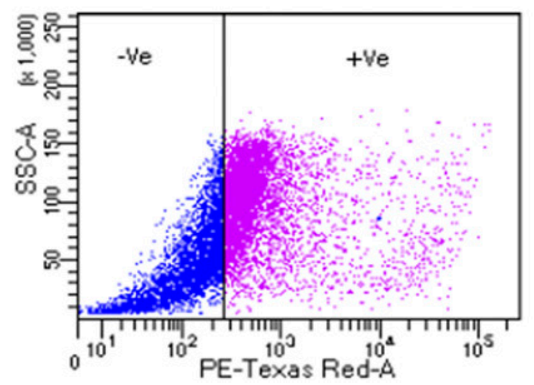

B

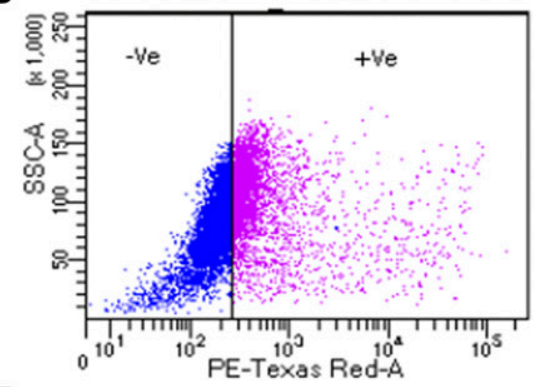

$\mathbf{E}$

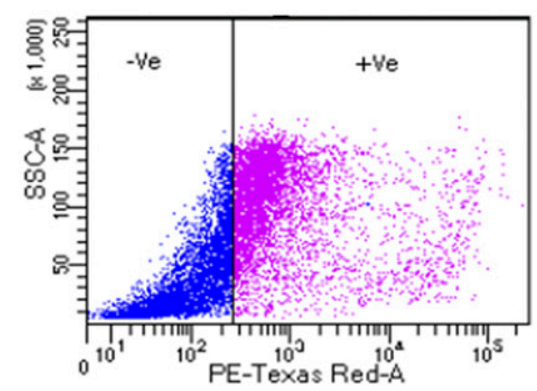

C

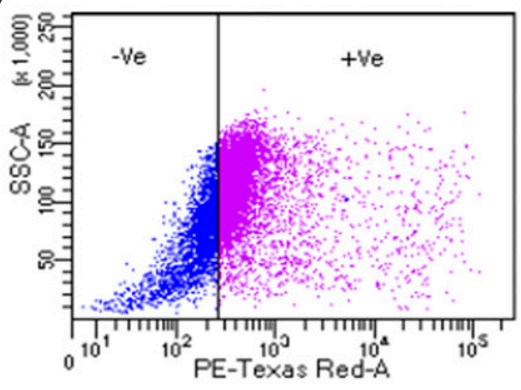

Fig. 3. Live dead assay to determine the percentage of cell death after treatment with (A) $0.1 \%$ DMSO, (B) $2 \mathbf{a}(4 \mu \mathrm{M}),(\mathrm{C}) \mathbf{2 a}(8 \mu \mathrm{M})$, (D) $2 \mathbf{l}(4 \mu \mathrm{M})$, and (E) $21(8 \mu \mathrm{M})$. The blue dots represent the PI-negative (live) cells, and magenta dots represent PI-positive (dead) cells. The experiment was repeated three times, and the quantitation is represented as mean \pm S.D. of three independent sets in Table 3.PE, phycoerythrin; SSC, side scatter; -Ve, negative; +Ve, positive

tubulin were deleted using PyMOL (DeLano, 2002). The final coordinates used for docking had one $\alpha$ subunit, one $\beta$ subunit, one GDP, one GTP, one calcium ion, and two magnesium ions. Initially global docking was performed by covering the whole molecule in a grid box of $72 \times 102 \times 100 \AA$, with grid spacing of $1 \AA$. The global docking was performed five times with exhaustiveness of 100 (the number of times the calculation is repeated), and each set of docking produced nine conformations. The greatest number of conformations were found to interact with two sites on the protein ( 16 conformations at the interface of the $\alpha$ - and $\beta$-dimers and 19 conformations at the taxol site) (Jaghoori et al., 2016). These two sites were thus chosen to perform local docking, which was performed in a grid box of $72 \times 56 \times 58 \AA$ for colchicine and $126 \times 86 \times 82 \AA$ for epothilone, with a grid spacing of $0.375 \AA$. The conformation with minimum binding energy was chosen to analyze the interaction with tubulin. Control docking with epothilone was performed in a similar way to validate the docking protocol. The coordinates of epothilone and colchicine were obtained from their PDB structures 4O4I and 1SA0, respectively. The interaction of the docked conformers with tubulin was further analyzed in University of California, San Francisco's (UCSF) Chimera version 1.11 (Pettersen et al., 2004) to determine the amino acid residues in the binding pocket and the residues within $4 \AA$ of $\mathbf{2 l}$ to determine the possible hydrogen bonding interactions.

Competitive Inhibition with Paclitaxel. Tubulin $(12 \mu \mathrm{M})$ was incubated with different concentrations $(0,2,5,10,20$, and $30 \mu \mathrm{M})$ of 21 for 10 minutes on ice in PEM buffer $\mathrm{pH}$ 6.8. Different concentrations $(2,5$, and $7 \mu \mathrm{M})$ of paclitaxel were added to the reaction mixtures for each concentration of $\mathbf{2 l}$ and incubated for 10 minutes on ice. The polymerization reaction was monitored immediately after adding $1 \mathrm{mM}$ GTP in Spectramax M2e by taking OD at $350 \mathrm{~nm}$. The percentage inhibition of tubulin polymerization versus concentration of 21 was plotted in a Lineweaver-Burk plot at different concentrations of paclitaxel to determine the nature of inhibition.

Effects of 21 on the Polymerization of spnFtsZ. Purified spnFtsZ $(10 \mu \mathrm{M})$ was polymerized in the presence of $1 \mathrm{mM}$ GTP at $37^{\circ} \mathrm{C}$ as described previously (Dhaked et al., 2019). The polymerization reaction was monitored in a spectrofluorometer
(FP-6500; JASCO) with the wavelength for both excitation and the emission at $400 \mathrm{~nm}$. Polymerization of spnFtsZ was also observed with prior incubation of the protein with $20 \mu \mathrm{M} \mathbf{2 a}$ and $\mathbf{2 l}$ in ice for 10 minutes.

Alkaline Phosphatase Assay. Two units of alkaline phosphatase was taken in glycine- $\mathrm{NaOH}$ buffer $\mathrm{pH} 10.4$ with $1 \mathrm{mM} \mathrm{MgCl}_{2}$ and $0.1 \mathrm{mM} \mathrm{ZnCl}_{2}$. Two hundred fifty micromolars of paranitrophenylphosphate was mixed with the reaction mixture in a cuvette. The reaction mixture was immediately put in a spectrophotometer, and the conversion of the yellow colored product was monitored by taking the OD at $410 \mathrm{~nm}$. A similar experiment was performed with both $\mathbf{2 a}$ and $\mathbf{2 l}$ by incubating $20 \mu \mathrm{M}$ each of $\mathbf{2 a}$ and 21 for 10 minutes with alkaline phosphatase on ice.

Sulphorhodamine B Assay. The $\mathrm{GI}_{50}$ in HeLa cells was determined by sulphorhodamine B assay as described previously (Vichai and Kirtikara, 2006). Briefly, HeLa cells were seeded in tissue culture treated 96 -well plate (10,000 cells/well). After attachment, the cells were treated with different concentrations of $\mathbf{2 a}$ and $\mathbf{2 1}$ and incubated for 24 hours followed by fixation with $50 \%$ trichloroacetic acid for 1 hour at $4^{\circ} \mathrm{C}$. The plates were then washed, dried, and stained with $0.4 \%$ sulphorhodamine $\mathrm{B}$ for 1 hour at room temperature. After drying of the plates, the dye was dissolved in $10 \mathrm{mM}$ Tris $\mathrm{pH} 10.5$, and the absorbance was measured at $520 \mathrm{~nm}$ in Spectramax $\mathrm{M}^{\mathrm{e}}$. The percentage

\section{TABLE 3}

Quantification of percentage of live and dead cells after treatment with bis(styryl)pyrazoles $\mathbf{2 a}$ and $\mathbf{2 1}$

\begin{tabular}{lc}
\hline Compound & Dead cells \\
\hline & $\%$ \\
Control & $15.4 \pm 1.2$ \\
$\mathbf{2 a}(4 \mu \mathrm{M})$ & $35.9 \pm 8.9$ \\
$\mathbf{2 a}(8 \mu \mathrm{M})$ & $54.5 \pm 12.2$ \\
$\mathbf{2 1}(4 \mu \mathrm{M})$ & $49.4 \pm 10.8$ \\
$\mathbf{2 1}(8 \mu \mathrm{M})$ & $47.4 \pm 6.0$ \\
\hline
\end{tabular}



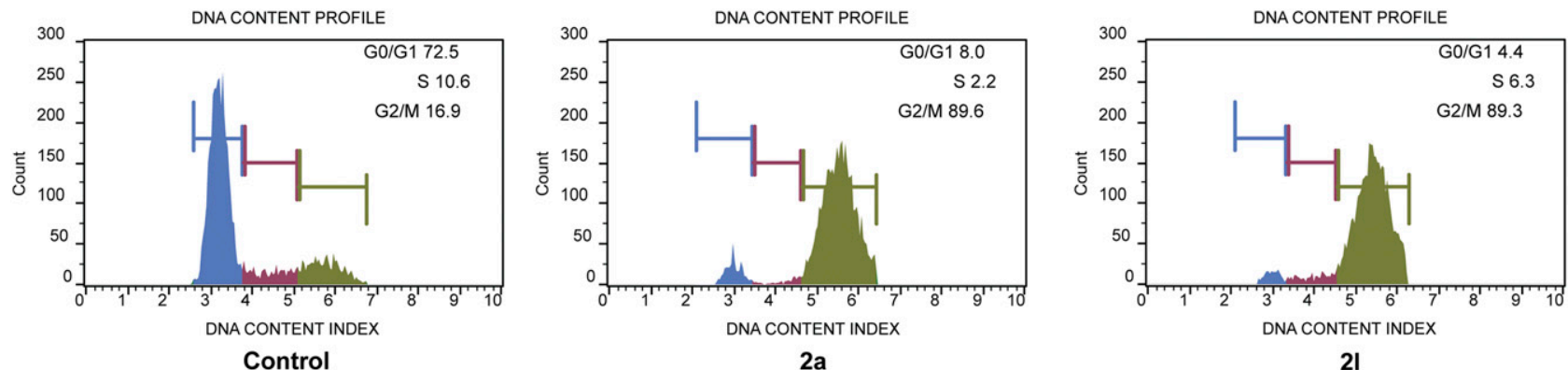

Fig. 4. Representative cell cycle histograms for PC3 cells 72 hours after treatment with vehicle control $(0.01 \%$ of DMSO) and GI 50 concentrations of analogs $2 \mathbf{a}$ and $2 \mathbf{l}$, where blue, magenta, and green represent the numbers of cells in the $\mathrm{G}_{0} / \mathrm{G}_{1}, \mathrm{~S}$, and $\mathrm{G}_{2} / \mathrm{M}$ phases, respectively.

inhibition of cell proliferation at each concentration was determined by the formula

$$
\text { \%Inhibition of cell proliferation }=100-\left\{\left(\frac{N_{t}-N_{0}}{N_{c}-N_{0}}\right) \times 100\right\},
$$

where $\mathrm{N}_{\mathrm{t}}$ is $\mathrm{OD}$ of the wells where $\mathbf{2 a}$ or $\mathbf{2 l}$ was added, $\mathrm{N}_{0}$ is the OD of the wells at the time of $\mathbf{2 a}$ or $\mathbf{2 l}$ addition, and $\mathrm{N}_{\mathrm{c}}$ is the OD of the wells of $0.1 \%$ DMSO treatment. This percentage inhibition was then fitted in dose-response inhibition curve in GraphPad Prism software.

Immunofluorescence Microscopy. The coverslips were first coated with poly-L-lysine, and then cells were added onto coverslips $(25,000$ cells/well $)$ for attachment. After attachment, cells were treated with different concentrations of $\mathbf{2 a}$ and $\mathbf{2 l}$ and incubated for 24 hours. Cells were then fixed with $4 \%$ formaldehyde and permeabilized with $100 \%$ chilled methanol. Two percent bovine serum albumin was used for blocking the nonspecific binding of the antibody, and then the anti- $\alpha$-tubulin antibody (Sigma) was added to cells and incubated for 3 hours at $37^{\circ} \mathrm{C}$. After washing of primary antibody, secondary antibody tagged with fluorescein isothiocyanate (Sigma) was added to the cells and incubated for 1.5 hours. The coverslips were mounted on clean glass slides using the mounting media having 4',6diamidino-2-phenylindole, purchased from Vector Laboratories, and observed under a fluorescence microscope (CSU-XI; Yokogawa).

Live-Dead Assay. The percentage of the live and dead cell was determined by propidium iodide (PI) staining. The cells were seeded up to $50 \%$ confluency in T25 flasks and then incubated with 4 and $8 \mu \mathrm{M}$ of $\mathbf{2 a}$ and $\mathbf{2 l}$ for 24 hours. The cells were trypsinized, pelleted, and resuspended in PBS with a final concentration of cells approximately 1 million per ml. The cells were stained with PI and then analyzed by flow cytometry for PI-positive and PI-negative cells. Ten thousand cells were counted in each case. The experiment was repeated three times.

Statistical Analysis. " $\pm ”$ represents S.D., and $P$ values were calculated using Student's $t$ test.

\section{Results}

Synthetic Chemistry. The synthesis of the bis(styryl) pyrazoles 2a-1 takes advantage of our recently described

\section{TABLE 4}

Percentage of live and dead PC3 cells $72 \mathrm{~h}$ after the removal of the 3,5bis(styryl)pyrazoles $\mathbf{2 a}$ and $\mathbf{2 1}{ }^{a}$

\begin{tabular}{lcc}
\hline Compound & Live cells & Dead cells \\
\hline & & $\%$ \\
Control & $95.7 \pm 2.2$ & \\
$\mathbf{2 a}$ & $86.7 \pm 3.5$ & $3.9 \pm 1.9$ \\
$\mathbf{2 l}$ & $67.5 \pm 9.1$ & $12.3 \pm 3.7$ \\
& & $29.4 \pm 9.8$
\end{tabular}

${ }^{a}$ Data represent the mean \pm S.D. of three independent replicates $(n=3)$. microwave-assisted synthesis of curcuminoids (Groundwater et al., 2017), in which the total reaction time was shortened to 10 minutes and the analytically pure compounds were mostly obtained by the simple recrystallization from ethanol of the crude solid obtained from the acid hydrolysis of the boroncontaining intermediate. The ready availability of these synthetic intermediates 1a-l lead to the preparation of

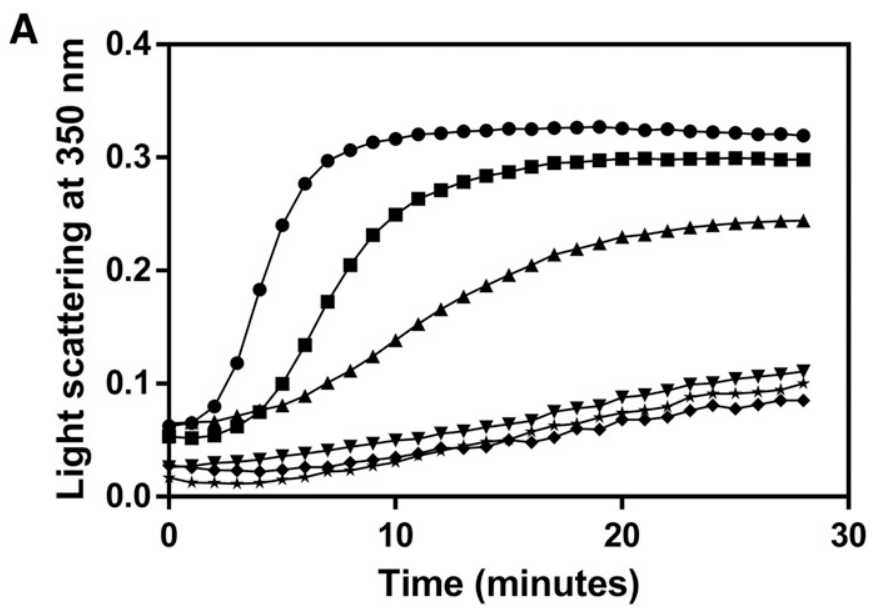

B

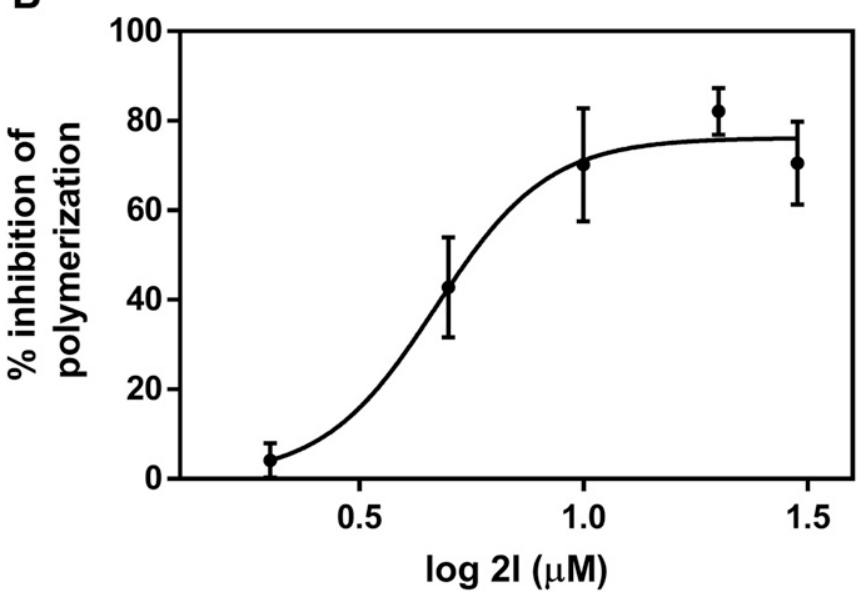

Fig. 5. Inhibition of tubulin polymerization by 3,5-bis(styryl)pyrazole $\mathbf{2 l}$ monitored by light scattering. Tubulin $(12 \mu \mathrm{M})$ was polymerized in the presence of $10 \%$ DMSO and $1 \mathrm{mM}$ GTP without $(\bullet)$ or with $2(\bullet), 5(\boldsymbol{\Delta}), 10$ $(\boldsymbol{\nabla}), 20(\star)$, and $30(\star) \mu \mathrm{M} 2 \mathbf{2}$. The polymerization kinetics were followed by light scattering at $350 \mathrm{~nm}$. The experiment was repeated three times. (A) Representative graph of the light scattering of tubulin in the presence and absence of 21. (B) The inhibition of tubulin polymerization at different concentrations of 2l. Error bars represent S.D. 

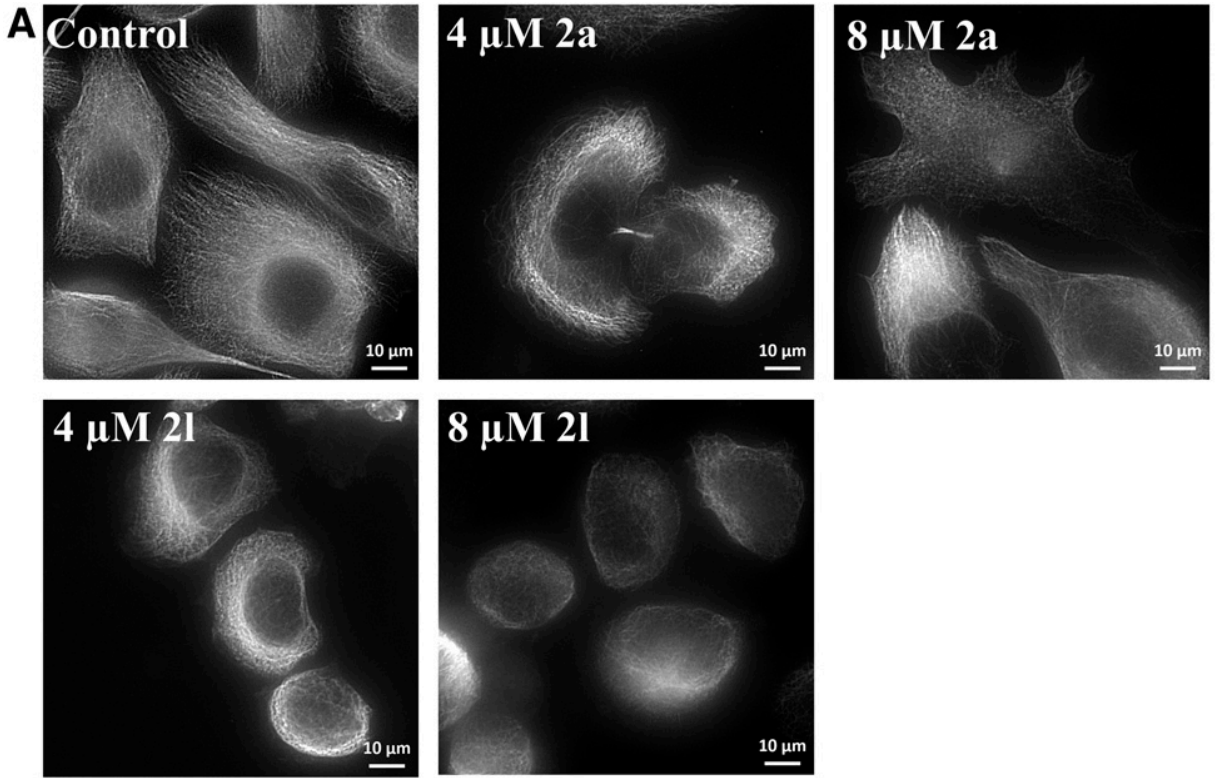

Fig. 6. Effect of $2 \mathbf{l}$ and $2 \mathbf{a}$ on microtubules of PC3 cells. (A) Interphase microtubules of PC3 cells before and after the treatment with 4 and $8 \mu \mathrm{M}$ of $\mathbf{2 a}$ and $\mathbf{2 l}$ (grayscale image). (B) Mitotic microtubules (green) and corresponding DNA (grayscale image). Scale bars, $10 \mu \mathrm{m}$.

B
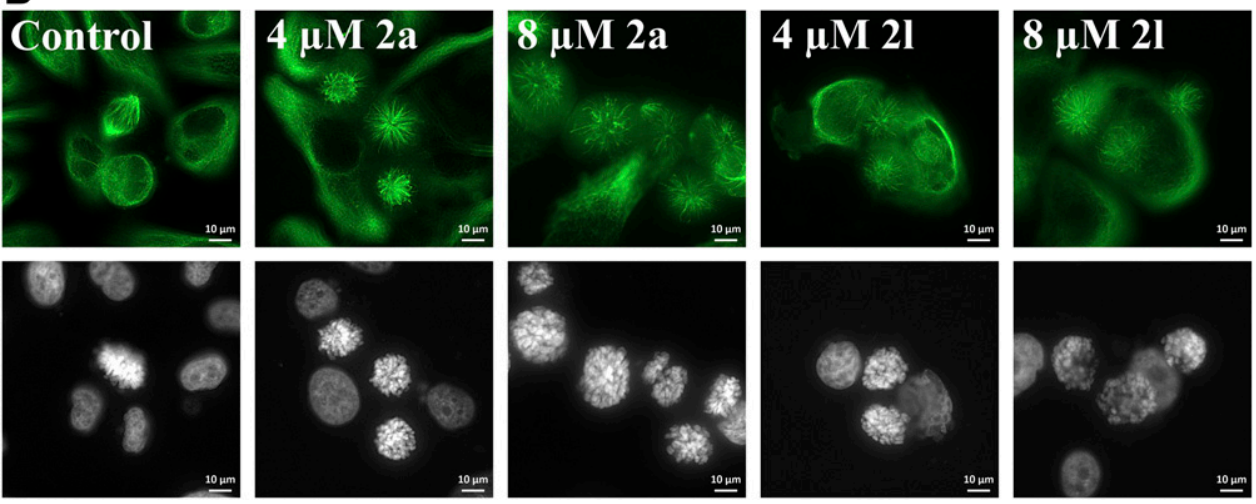

noncurcuminoid analogs such as 3,5-bis(stryryl)pyrazole analogs $2 \mathbf{a}-1$ for biologic evaluation, via the cyclization with hydrazine in an acid-catalyzed microwave-assisted condensation, to generate the respective 2a-l (Scheme 1).

Antiproliferative Activity of 3,5-Bis(styryl)pyrazoles 2a-1 in PC3 Cells. The growth inhibitory effect of all the 3,5-bis(styryl)pyrazoles 2a-l on the PC3 cell line was determined by the MTT assay (Table 2), which was validated by the trypan blue exclusion cell count. Methotrexate was used as a positive control, with a $\mathrm{GI}_{50}$ value (obtained in this study) of $0.012 \pm 0.008 \mu \mathrm{M}$, which is within the ranges of the reported $\mathrm{GI}_{50}$ values in PC3 cells for methotrexate (0.001-0.1 $\mu \mathrm{M})$ (Derenne et al., 2010; Marques et al., 2010; Serova et al., 2011). Two compounds (2a and $\mathbf{2 l}$ ) had $\mathrm{GI}_{50}$ values in the low micromolar range $(<2.5 \mu \mathrm{M})$ (Supplemental Fig. 1) and were thus selected for further biologic evaluation, as well as degradation and solubility studies.

Degradation Studies. We evaluated the stability and solubility of the two analogs selected for extensive biologic testing, $\mathbf{2 a}$ and $\mathbf{2 l}$, under simulated physiologic conditions $(\mathrm{pH}$ $7.4,37^{\circ} \mathrm{C}$ ), and the degradation kinetics are summarized in Fig. 1. After 24 hours under the simulated physiologic conditions, $10 \%$ of analog 2 a remained, whereas $71 \%$ of analog 21 remained after 72 hours (Supplemental Figs. 2 and 3).
The Effect of 3,5-Bis(styryl)pyrazoles $2 a$ and 21 on the Induction of Apoptosis in PC3 Cells. The two selected analogs $(\mathbf{2 a}$ and $\mathbf{2 l})$ did not induce apoptosis at their $\mathrm{GI}_{50}$ concentrations, as determined by the annexin V/PI apoptosis assay. PC3 cells were treated at the $\mathrm{GI}_{50}$ of analogs $\mathbf{2 a}$ and $\mathbf{2 l}$, with cells treated with DMSO $(0.01 \%)$ as the vehicle control. The cells were then incubated for 72 hours, stained with annexin V/PI, and analyzed. The representative dot plots depicting the results from this apoptosis assay are shown in Fig. 2; cells treated with and without these compounds maintained more than $90 \%$ viability, indicating that they did not undergo apoptosis when treated at the $\mathrm{GI}_{50}$ concentrations. However, the cells died after treatment with higher concentrations of $\mathbf{2 a}$ and $\mathbf{2 l}(4$ and $8 \mu \mathrm{M})$, as shown by the increasing number of PI-positive cells after PI staining and counting 10,000 cells by flow cytometry (Fig. 3; Table 3). In addition, we quantified the extent of apoptosis in three other cell lines, namely, lung carcinoma (A549), skin melanoma (B16F10), and liver carcinoma (Huh-7), at similar concentrations of $\mathbf{2 a}$ and $\mathbf{2 1}$. The compounds induced apoptosis in all three cell lines in a concentration-dependent manner (Supplemental Fig. 4; Supplemental Table 3).

The Effect of 3,5-Bis(styryl)pyrazoles $2 \mathrm{a}$ and 21 on the Cell Cycle of PC3 Cells. A cell cycle analysis was conducted 

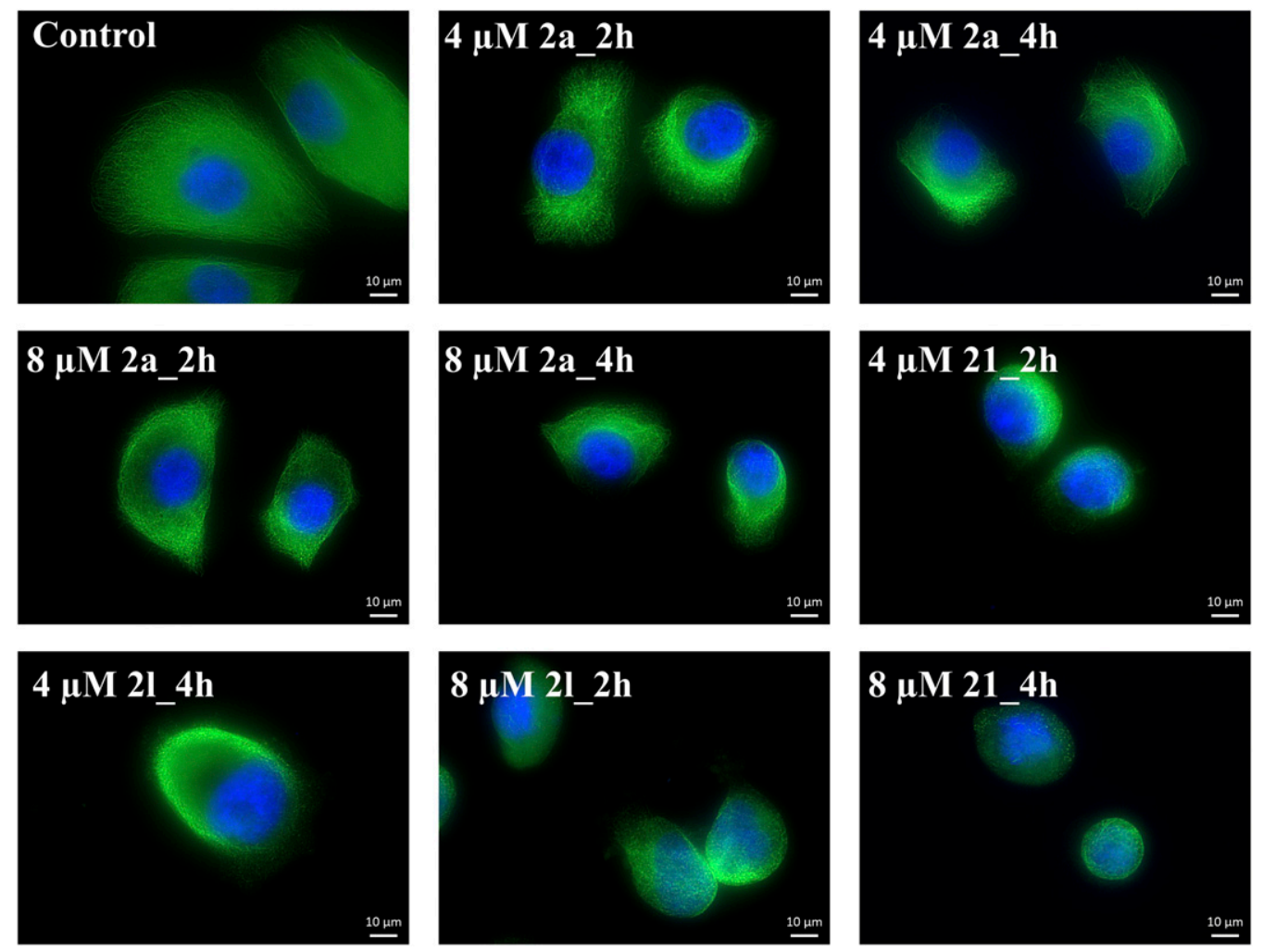

Fig. 7. Effects of $\mathbf{2 1}$ and $\mathbf{2 a}$ on microtubules of PC3 cells after 2 and 4 hours of $\mathbf{2 a}$ and $\mathbf{2 1}$ treatment. Interphase microtubules (green) of PC3 cells before and after the short exposure of 4 and $8 \mu \mathrm{M}$ of $\mathbf{2 a}$ and $\mathbf{2 l}$. DNA (blue) was stained with Hoechst 33258. Scale bars, $10 \mu \mathrm{m}$.

to determine the effects of 3,5-bis(styryl)pyrazoles $\mathbf{2 a}$ and $\mathbf{2 1}$ on cell division. PC3 cells were treated for 72 hours at the $\mathrm{GI}_{50} \mathrm{~s}$ of these compounds, with cells treated with $0.01 \%$ of DMSO used as the vehicle control. The cell cycle analysis showed a significant increase in the percentage of cells in the $\mathrm{G}_{2} / \mathrm{M}$ phase when treated with the 3,5-bis(styryl)pyrazoles at their $\mathrm{GI}_{50}$ concentrations, in comparison with the control (Fig. 4; Supplemental Table 4).

Assessment of the Outcome of Mitotic Arrest Induced by 3,5-Bis(styryl)pyrazoles $2 a$ and 21 . To evaluate the potential of 3,5-bis(styryl)pyrazoles $\mathbf{2 a}$ and $\mathbf{2 l}$ as effective agents for the treatment of CRPC, we examined whether cell death results from mitotic arrest in PC3 cells. PC3 cells were treated for 72 hours with 3,5-bis(styryl)pyrazoles $2 \mathbf{2 a}$ and $\mathbf{2 l}$ (at their $\mathrm{GI}_{50} \mathrm{~s}$ ), and the medium containing the compounds was then removed and replaced with fresh medium. The cells were incubated for a further 72 hours before being stained with annexin V/PI and analyzed. The percentage of cell death 72 hours after the removal of $\mathbf{2 a}$ and $\mathbf{2 l}$ (Supplemental Fig. 5; Table 4) was lower than the mitotic block after 72 hours treatment with $\mathbf{2 a}$ and $\mathbf{2 l}$ (Supplemental Table 4), suggesting that the effects of the compounds on PC3 cells are reversible.

Determination of the Effect of 3,5-Bis(styryl)pyrazoles 2a and 21 on Tubulin Polymerization. Since both the compounds, $\mathbf{2 a}$ and $\mathbf{2 l}$, caused a mitotic block, a characteristic of most antitubulin agents (Mukhtar et al., 2014), the effect of $\mathbf{2 a}$ and $\mathbf{2 l}$ on tubulin was investigated. 3,5-Bis(styryl) pyrazole $\mathbf{2 l}$ inhibited the polymerization of purified tubulin (Fig. 5), inhibiting both the rate and extent of tubulin assembly, as monitored by light scattering. The extent of inhibition of tubulin polymerization by the compound was also determined by the sedimentation assay (Supplemental Fig. 6). The $\mathrm{IC}_{50}$ of 3,5-bis(styryl)pyrazole $\mathbf{2 l}$ for tubulin polymerization was found to be $4.7 \pm 1.2 \mu \mathrm{M}$ by light scattering and $4 \pm$ $1.5 \mu \mathrm{M}$ by the sedimentation assay.

The effect of analog $\mathbf{2 a}$ on the polymerization of purified tubulin was also determined by light scattering and sedimentation assay (Supplemental Fig. 7). Unlike the pyrazole 2l, analog $\mathbf{2 a}$ was not able to inhibit the tubulin polymerization in vitro (Supplemental Fig. 7).

Effect of 3,5-Bis(styryl)pyrazoles $2 a$ and 21 on Microtubules of PC3 Cells. Next, the effects of 3,5-bis(styryl) pyrazoles $2 \mathbf{a}$ and $2 \mathbf{l}$ on the microtubules of PC3 cells were examined by fluorescence microscopy. Cells were seeded on poly-L-lysine coated coverslips and treated with 4 and $8 \mu \mathrm{M}$ of 2a or 21. Both the compounds caused the depolymerization of the interphase microtubules in PC3 cells (Fig. 6A). As in the control cells, thread-like microtubule structures can be seen, which were well spread in the cytoplasm of the cells. These thread-like structures were not properly visible in cells treated with $\mathbf{2 a}$ and $\mathbf{2 l}$, indicating that the interphase microtubules were depolymerized by the treatment with these drugs (Fig. 6A). Although both $2 \mathbf{2}$ and 21 also strongly depolymerized spindle microtubules and caused the formation of abnormal spindles in PC3 cells (Fig. 6B), the effects of 21 on interphase microtubules were more pronounced (Supplemental Fig. 8A). A normal mitotic cell with spindle microtubules is shown in the Fig. 6B control panel (arrow). In treated cells, abnormal multipolar spindles can be seen, and the number of mitotic cells per field increased significantly after the treatment with 2a and 2l, which also confirms that these compounds cause mitotic block (Fig. 6B; Supplemental Fig. 8B). In the control cells, 
Control

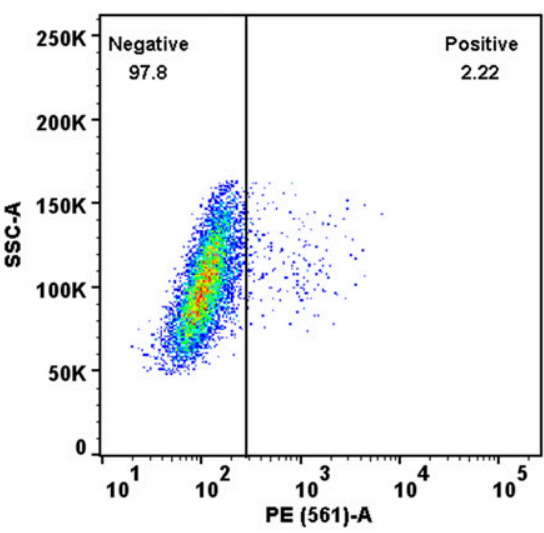

$4 \mu M$ 21_2h

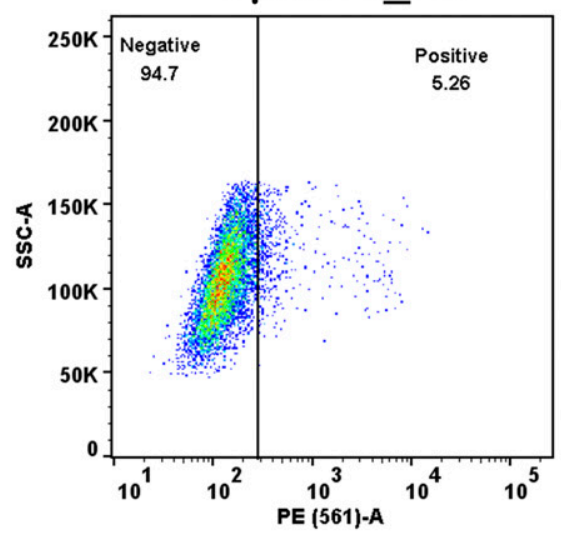

$8 \mu M$ 2a_4h

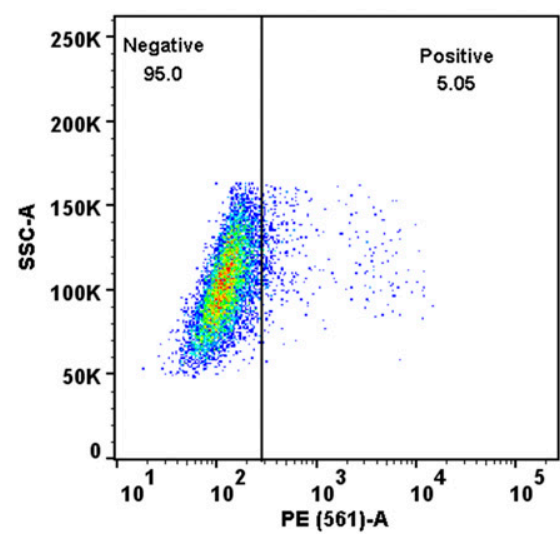

$4 \mu \mathrm{M} 2 \mathrm{a} 2 \mathrm{~h}$

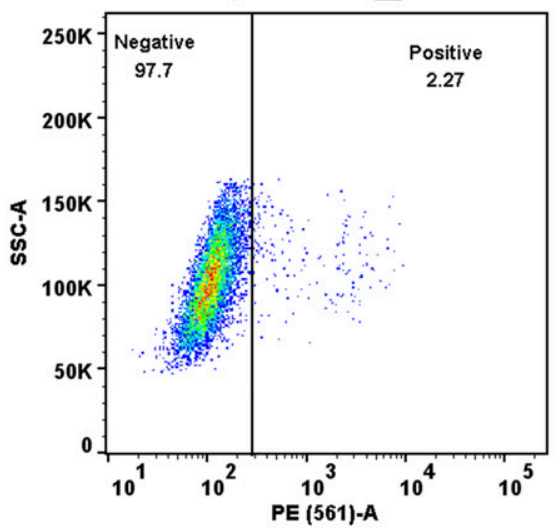

$4 \mu M$ 21_4h

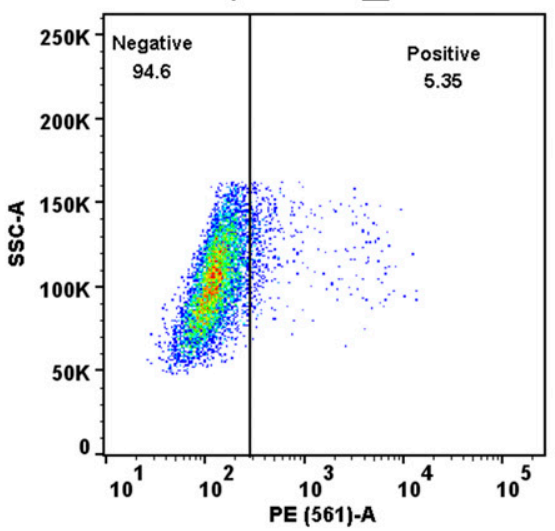

$8 \mu M$ 2l_2h

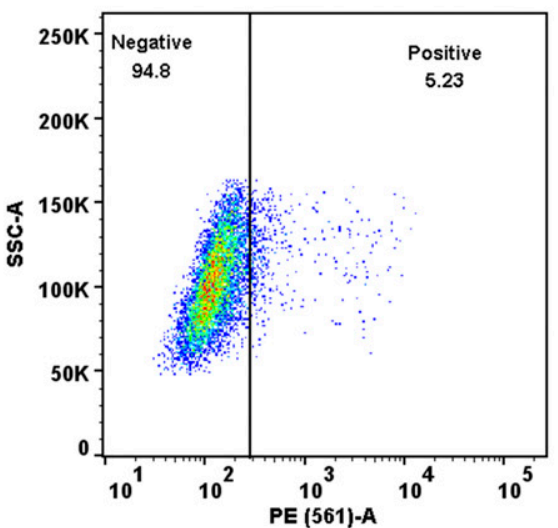

$4 \mu M$ 2a_4h

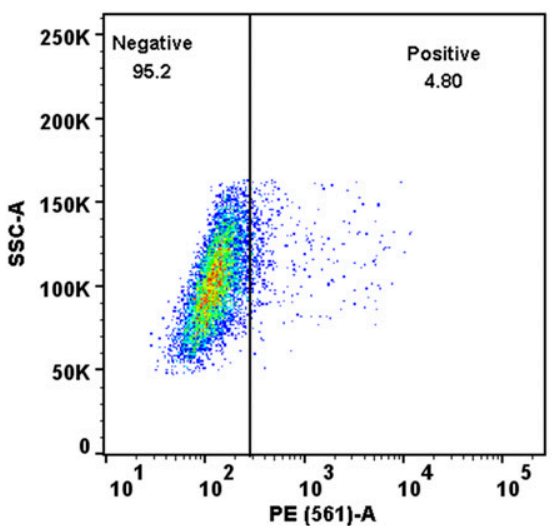

$8 \mu$ M 2a_2h

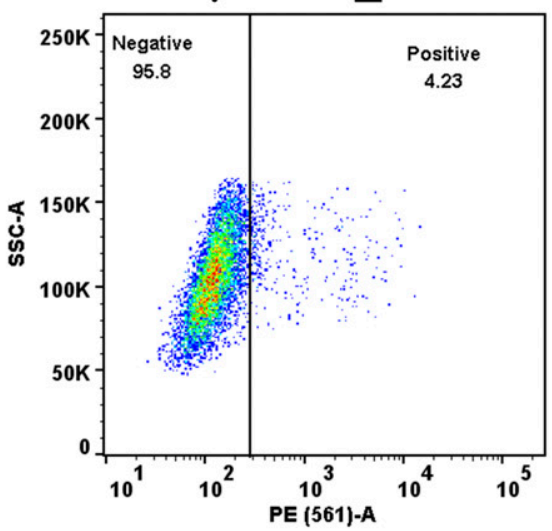

$8 \mu M$ 2l_4h

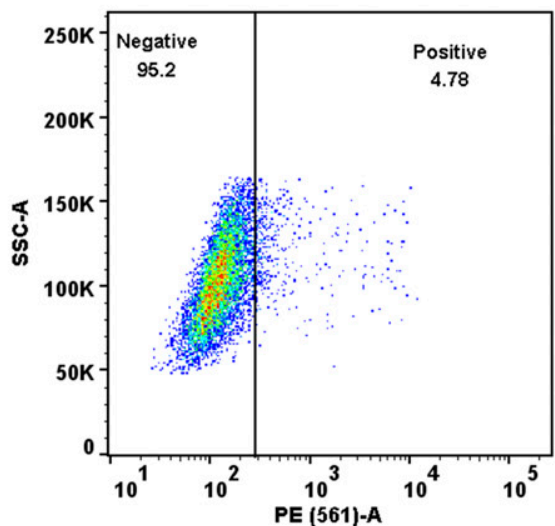

Fig. 8. Live dead assay to determine the percentage of cell death after treatment with 4 and $8 \mu \mathrm{M}$ of $\mathbf{2 a}$ and $2 \mathbf{l}$ for 2 and 4 hours. The experiment was repeated three times, and the quantitation is represented as mean \pm S.D. of three independent sets in Supplemental Table 5.PE, phycoerythrin; SSC, side scatter

DNA is aligned on the metaphase plate (arranged more compactly in a straight line), whereas after treatment the DNA is scattered and unable to align. We also determined the effect of $\mathbf{2 a}$ and $\mathbf{2 l}$ on the microtubules of HeLa cells. The $\mathrm{GI}_{50}$ of $\mathbf{2 a}$ and $\mathbf{2 l}$ was determined to be $2.6 \pm 1.2$ and $2.4 \pm 0.5 \mu \mathrm{M}$, respectively (Supplemental Fig. 9, A and B). Both 2a and $2 \mathbf{l}$ depolymerized interphase and spindle microtubules in HeLa cells (Supplemental Fig. 9, C and D), with the depolymerization of microtubules by $\mathbf{2 l}$ being more pronounced than that produced by $\mathbf{2 a}$ (Supplemental Fig. 10A). The population of mitotic cells also increased upon treatment with $\mathbf{2 a}$ and $\mathbf{2 1}$, suggesting that the compounds cause mitotic block (Supplemental Fig. 10B).

Kinetics of Microtubule Depolymerization and Cell Death after Treatment of PC3 Cells with 3,5-Bis(styryl) pyrazole 2a. To examine whether microtubules are the primary targets of $\mathbf{2 a}$ and $\mathbf{2 1}$, we compared the kinetics of microtubule disassembly and cell death upon treatment with both compounds. PC3 cells were incubated without or with either 4 and $8 \mu \mathrm{M}$ of $\mathbf{2 a}$ and $\mathbf{2 l}$ for 2 and 4 hours. The fluorescence intensity of microtubules was found to be 
strongly reduced after both 2- and 4-hour treatment with $2 \mathbf{a}$ and 21 (Fig. 7; Supplemental Fig. 11). The fluorescence intensity of microtubules in vehicle treated cells was determined to be $1525 \pm 229$ (a.u.), dropping to $1054 \pm$ 112 and $913 \pm 105$ (a.u.) after treatment with $4 \mu \mathrm{M} \mathbf{2 a}$ for 2 and 4 hours, respectively, and $825 \pm 61$ and $771 \pm 54$ (a.u.) after treatment with $4 \mu \mathrm{M} 21$ for 2 and 4 hours, respectively (Fig. 7; Supplemental Fig. 11). The fluorescence intensity of the microtubules was reduced by 54 and $57 \%$ in the presence of $8 \mu \mathrm{M} 2 \mathbf{2 a}$ for 2 and 4 hours, and 41 and $72 \%$ in the presence of $8 \mu \mathrm{M} 21$ for 2 and 4 hours, respectively (Fig. 7; Supplemental Fig. 11). These results indicate that treatment with both $\mathbf{2 a}$ and $\mathbf{2 l}$ led to the formation of depolymerized microtubules within a short time period. In contrast, treatment with 4 and $8 \mu \mathrm{M} \mathbf{2 a}$ and 21, for 2 or 4 hours, did not induce cell death in PC3 cells (Fig. 8; Supplemental Table 5), indicating that the depolymerization of microtubules preceded cell death upon treatment with $\mathbf{2 a}$ or $\mathbf{2 l}$ and that microtubules are the primary targets of both $\mathbf{2 a}$ and $\mathbf{2 1}$ in PC3 cells.

Binding of 3,5-Bis(styryl)pyrazole 21 to Tubulin. Since $\mathbf{2 a}$ and $\mathbf{2 l}$ caused microtubule depolymerization, we characterized the binding of $\mathbf{2 a}$ and $\mathbf{2 l}$ with tubulin; the binding of $\mathbf{2 l}$ with tubulin was examined by monitoring the tryptophan fluorescence of tubulin (Bhattacharyya et al., 2010). The fluorescence of tubulin was found to be reduced in the presence of $\mathbf{2 1}$, indicating that the compound binds to tubulin (Fig. 9). The change in the fluorescence intensity of tubulin in the presence of 21 was plotted in a binding isotherm, which yielded a $K_{d}$ of $0.4 \pm$ $0.1 \mu \mathrm{M}$ for the binding interaction.

The binding affinity of $\mathbf{2 a}$ to tubulin was also determined (Supplemental Fig. 12), and it was found that it binds to tubulin with a much weaker affinity $\left(\mathrm{K}_{\mathrm{d}}, 4.6 \pm 1.1 \mu \mathrm{M}\right)$ than $2 \mathrm{l}$ $\left(\mathrm{K}_{\mathrm{d}}, 0.4 \pm 0.1 \mu \mathrm{M}\right)$, a possible explanation for the weak effect of $\mathbf{2 a}$ on the polymerization of purified tubulin and interphase cellular microtubules.

Determination of Binding Site of 3,5-Bis(styryl)pyrazole 21 on Tubulin. Pyrazole 21 binds to tubulin with higher affinity than $\mathbf{2 a}$, and we have determined the binding site of 21 on tubulin. Tubulin has three well defined binding sites for small molecules: the taxane, vinca alkaloid, and colchicine sites (Supplemental Fig. 13). Compounds that bind to the vinca alkaloid and colchicine sites generally destabilize microtubules, so we first checked the binding of $\mathbf{2 l}$ to these binding sites.

The fluorescence intensity of colchicine and BODIPY-FLvinblastine increases upon binding to tubulin, whereas the absorbance of crocin, a vinca domain binder, increases upon binding to tubulin. If $\mathbf{2 l}$ inhibits the binding of colchicine to tubulin, the fluorescence of colchicine-tubulin complex should be reduced in the presence of $\mathbf{2 l}$. However, the prior incubation of 21 with tubulin did not reduce the fluorescence of colchicinetubulin complex, indicating that 21 does not bind to the colchicine site on tubulin (Supplemental Fig. 14A). To check the binding of $\mathbf{2 l}$ at the vinblastine site, we used BODIPY-FLvinblastine and crocin. There was no change in the fluorescence of the BODIPY-FL-vinblastine-tubulin complex or the absorbance of the crocin-tubulin complex, respectively, upon prior incubation with $\mathbf{2 1}$, indicating that $\mathbf{2 l}$ does not bind to the vinblastine site on tubulin (Supplemental Fig. 14, B and C).

Consequently, to determine the putative binding site, we performed molecular docking with the tubulin crystal structure

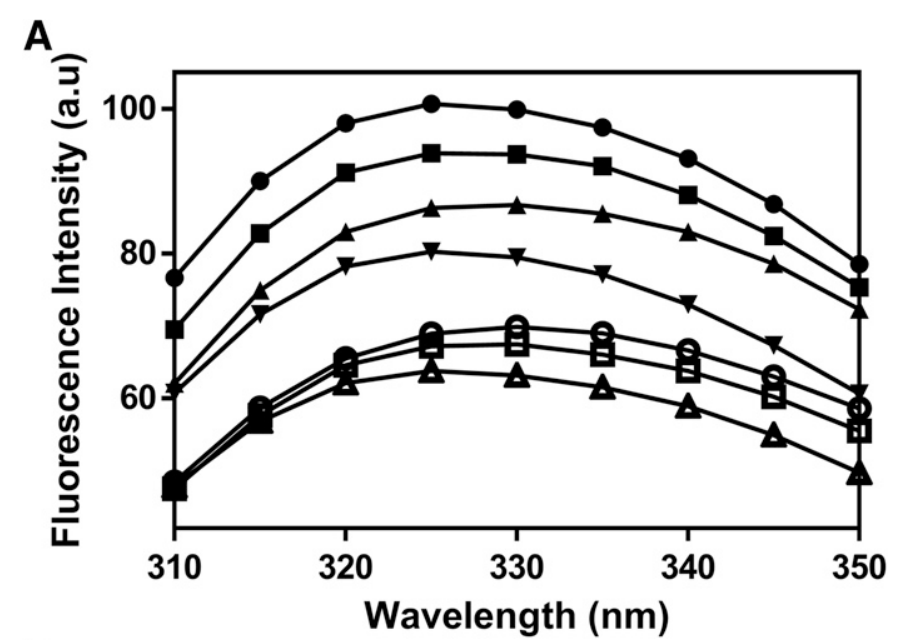

B

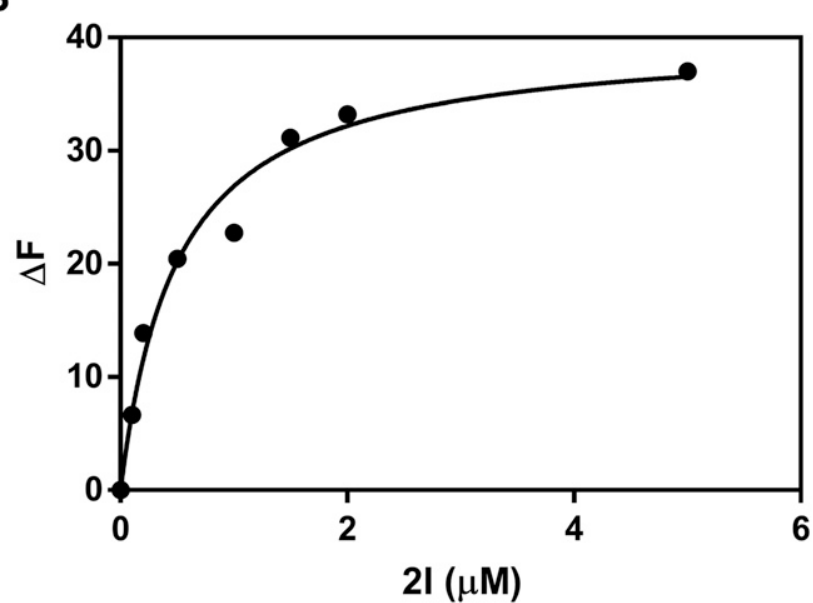

Fig. 9. Determination of the $K_{d}$ of the tubulin-2l complex. (A) The fluorescence of tubulin reduced with increasing concentration of $\mathbf{2 l}$ : $0(\bullet), 0.1(\bullet), 0.2(\boldsymbol{\Delta}), 0.5(\boldsymbol{\nabla}), 1.5(\bigcirc), 2(\square)$ and $5(\Delta) \mu \mathrm{M}$. (B) The difference in the fluorescence intensity $(\Delta \mathrm{F})($ at $340 \mathrm{~nm}$ ) of tubulin in the presence of various concentrations of the compound was fitted in a binding equation. The experiment was repeated three times.

(PDB identifier 5LYJ) as described previously (Rane et al., 2017; Hura et al., 2018). We found that most conformations of 21 were interacting with two distinct sites on tubulin; the paclitaxel binding site on $\beta$-tubulin (Fig. 10) and the interface of the $\alpha$ - and $\beta$-tubulin heterodimer (Supplemental Fig. 15), near the colchicine site. To further validate the docking, we docked epothilone, a paclitaxel site binder, with tubulin. The root mean square deviation of the docked conformation of epothilone to the epothilone conformation present in complex with tubulin (PDB identifier 404I) was found to be $1 \AA$, confirming that the docking protocols were appropriate (Fig. 11) (Hura et al., 2018). Since competitive binding data with colchicine showed that 21 does not bind to the colchicine site (Supplemental Fig. 14A), we further analyzed the docking data only for paclitaxel site.

We found that 21 possibly forms 2 hydrogen bonds in the paclitaxel binding site, with the peptide backbone of T273 $(2.2 \AA)$ and P271 (2.6 $\AA$ ) (Fig. 12). Further analysis of the docking gave the binding energy of 21 with tubulin, which was found to be $-8.4 \mathrm{kcal} / \mathrm{mol}$, whereas that of epothilone was found to be $-9.1 \mathrm{kcal} / \mathrm{mol}$. Taxol also forms a similar hydrogen bond with the peptide backbone of T273 (3.0 $)$. 
A

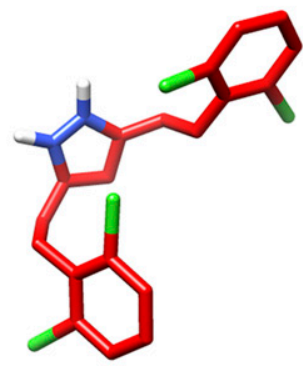

C

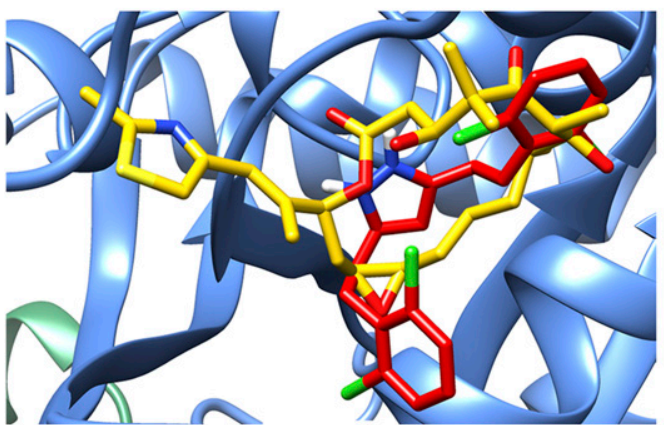

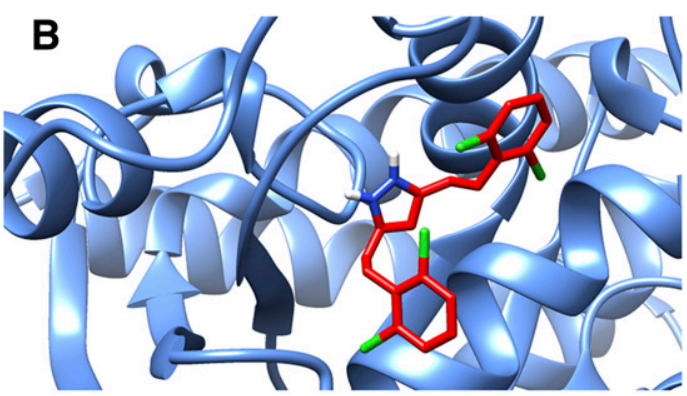

D

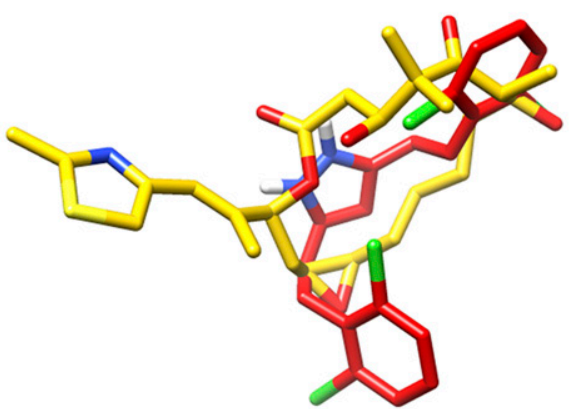

Fig. 10. Docking of 21 on tubulin. (A) Structure of 21 shown in red sticks. (B) Conformation of $2 \mathbf{l}$ (red sticks) docked with beta-tubulin (blue ribbon) with least binding energy. (C) Docked conformation of epothilone (yellow sticks) and 21 (red sticks) with beta-tubulin (blue ribbons) showing epothilone; 21 goes to the same binding pocket on beta-tubulin. (D) Magnified view of overlap between $2 \mathbf{l}$ and epothilone after docking.
In addition, paclitaxel also forms other hydrogen bonds,

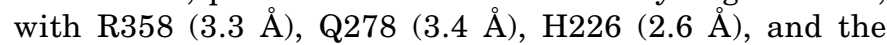
peptide backbone of R358 (3.1 A) (Snyder et al., 2001; Yadava et al., 2015).

We also analyzed the binding pocket of both epothilone and 21 on beta-tubulin and found that there were 12 residues that are common to both 21 and epothilone (Table 5), showing that $\mathbf{2 l}$ and epothilone share the same binding pocket. Since the taxol binding pocket has hydrophobic residues in the $\mathrm{H} 7$ helix, M loop, and $\beta$ strand of S7, S9-10, (Ranade et al., 2016), it is possible that 21 also makes some hydrophobic interactions within the binding pocket.

To elucidate the binding site of $\mathbf{2 l}$ on tubulin, we performed a competitive inhibition experiment of $\mathbf{2 l}$ with paclitaxel. The effects of $2 \mathbf{l}$ on the polymerization of tubulin in the presence of different concentrations of paclitaxel were determined. $2 \mathbf{l}$ exerted a stronger inhibitory effect on tubulin polymerization in the presence of low concentrations of paclitaxel. The percentage inhibition at each concentration of taxol was plotted in the Michaelis-Menten equation (Fig. 13A). The resulting curves showed a typical competitive inhibition pattern, where $\mathrm{V}_{\max }$ (maximum percentage of inhibition) remains unchanged $(P>0.05)$. Furthermore, the Lineweaver-Burk plot indicated that the nature of inhibition is competitive (Fig. 13B), as the plot shows that the affinity of the substrate $\mathbf{2 l}$ changes with changes in the paclitaxel concentration, as suggested by a decrease in the $x$-intercept with increasing concentration of paclitaxel.

Determination of the Effect of 3,5-Bis(styryl)pyrazoles $2 \mathrm{a}$ and 21 on spnFtsZ. 3,5-Bis(styryl)pyrazoles, $2 \mathbf{a}$ and 2l, inhibited neither the polymerization of spnFtsZ (a bacterial homolog of tubulin) nor the enzymatic activity of alkaline phosphatase (Fig. 14) suggesting that the compounds are not Pan-assay interference compounds.
A

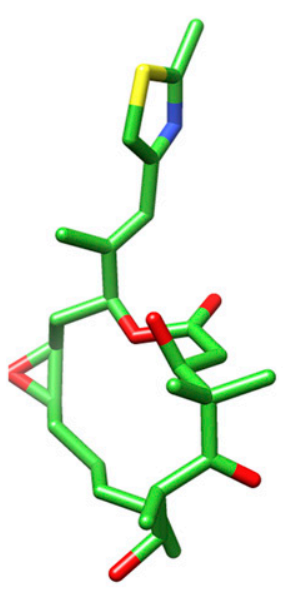

B

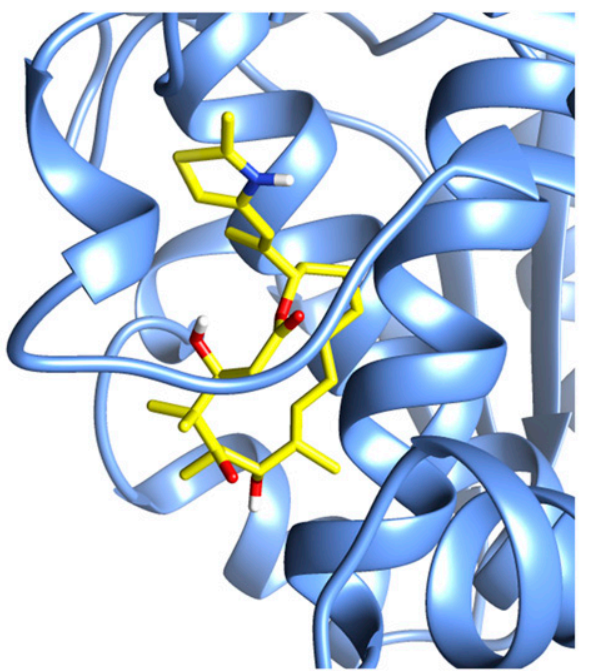

C

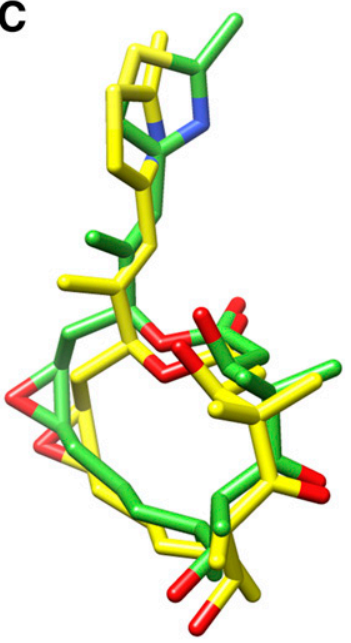

Fig. 11. Docking of epothilone with tubulin. (A) Crystal structure of epothilone (green sticks). (B) Docked conformation of epothilone (yellow sticks) with beta-tubulin (blue ribbon). (C) Root mean square deviation of the crystal structure (green) and docked conformation (yellow) of epothilone. 


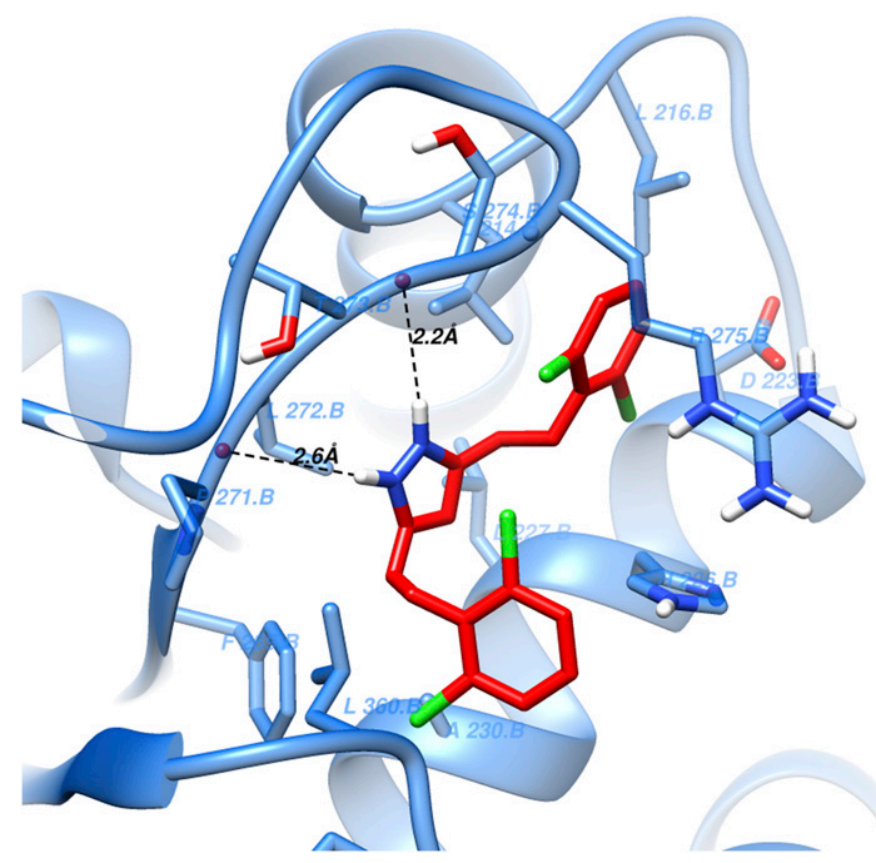

Fig. 12. Residues within 4 Å of $\mathbf{2 l}$ (red sticks) on beta-tubulin (blue ribbon) showing two possible hydrogen bonds.

\section{Discussion}

A range of 3,5-bis(styryl)pyrazole analogs 2a-l have been prepared using a very simple environmentally friendly microwave-assisted protocol, allowing the rapid and clean generation of analogs in minutes without the need for multiple chromatographic steps for purification. All analogs were screened for antiproliferative activity in the PC3 (androgenindependent) prostate cancer cell line, and two analogs (2a and 2l) with $\mathrm{GI}_{50}$ values in the low micromolar range were selected for further biologic evaluation. 3,5-Bis(styryl)pyrazole $2 \mathbf{a}$ was the most potent compound in the study of the antiproliferative activity in PC3 cells $\left(\mathrm{GI}_{50} 0.85 \pm 0.34 \mu \mathrm{M}\right)$, whereas the novel analog 21 was also selected for further biologic evaluation (Supplemental Fig. 1); it has been shown in other studies that analog $\mathbf{2 a}$ has $\mathrm{GI}_{50}$ values of $5.6 \mu \mathrm{M}$ (in PC3 cells) (Fuchs et al., 2009) and 4.19 and $0.25 \mu \mathrm{M}$ in breast cancer cell lines, MCF-7 and SKBR3, respectively (Amolins et al., 2009). The $\mathrm{GI}_{50}$ of $\mathbf{2 a}$ and $\mathbf{2} \mathbf{l}$ against human cervical cancer (HeLa) cells was determined to be $2.6 \pm 1.2$ and $2.4 \pm$ $0.5 \mu \mathrm{M}$, respectively (Supplemental Fig. 9).

In a stability study, we found that after 72 hours only $10 \%$ of derivative $2 \mathbf{a}$ remained, in comparison with the $71 \%$ of analog $\mathbf{2 1}$ that remained. The instability of $\mathbf{2 a}$ at $\mathrm{pH} 7.4$ may be due to the presence of the para-hydroxy group; a detailed study of the mechanism of degradation of 1a under physiologic conditions suggested that the major degradation pathway is auto-oxidation
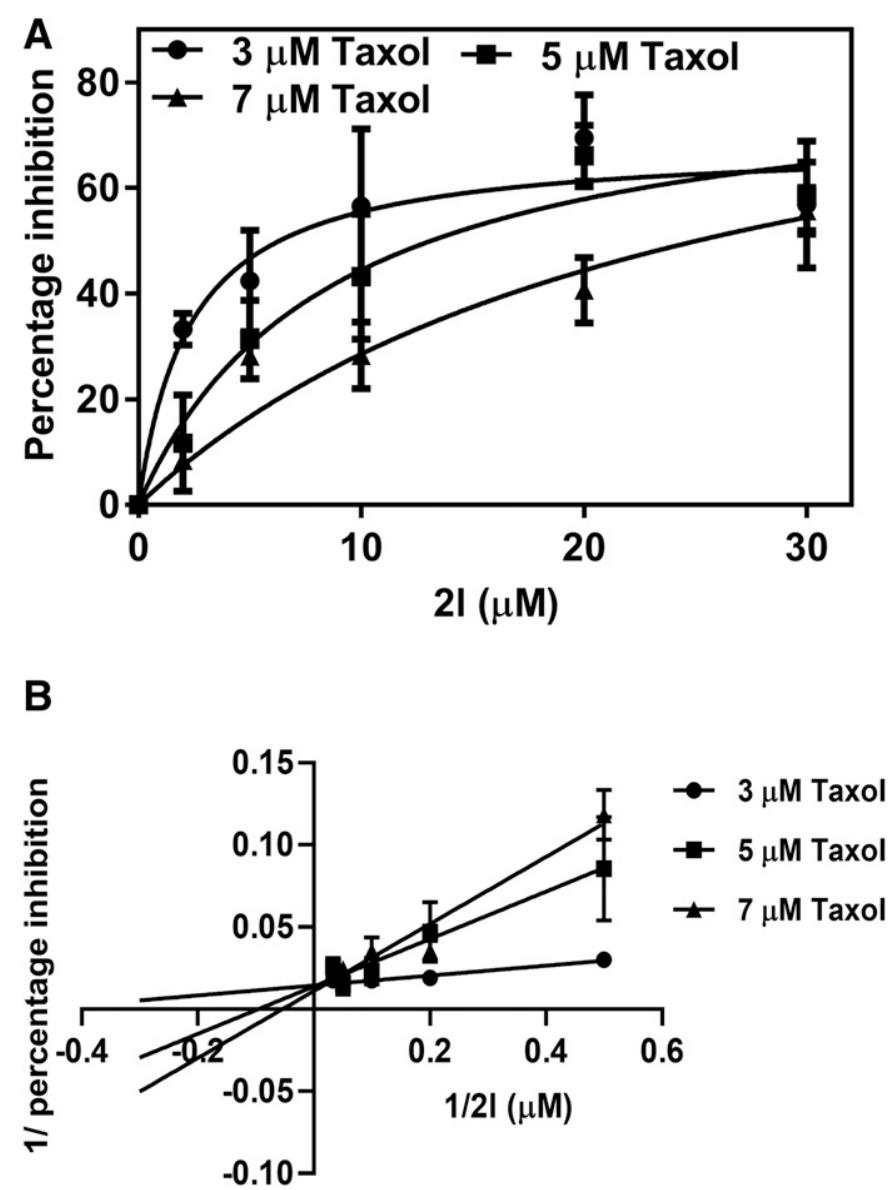

Fig. 13. Determination of the nature of inhibition of 21 by paclitaxel. (A) Percentage inhibition data fitted in Michaelis-Menten equation. (B) Lineweaver-Burk plot for $3(\bullet), 5(\bullet)$, and $7(\boldsymbol{\Delta}) \mu \mathrm{M}$ paclitaxel concentration showing that the nature of inhibition is competitive. The experiment was repeated three times, and error bars represent S.D.

due to the presence of this group (Gordon et al., 2015). As $2 \mathbf{a}$ is a derivative of 1a, it too could undergo similar auto-oxidation, leading to rapid degradation. Although the $\mathrm{GI}_{50}$ of $\mathbf{2 a}$ is less than that of 21,21 might thus be a better lead than 2a. Neither of these analogs induced apoptosis at their $\mathrm{GI}_{50}$ concentration, but, as can be seen from the cell cycle histograms in Fig. 4, both caused significant effects on the cell cycle, with the vast majority of treated cells in the $\mathrm{G}_{2} / \mathrm{M}$ phase $(89.6 \%$ and $89.3 \%$, respectively), suggesting that these analogs inhibit PC3 cell growth as a result of $\mathrm{G}_{2} / \mathrm{M}$ arrest. With no cell division, as a result of $\mathrm{G}_{2} / \mathrm{M}$ arrest, the percentage of cells in the $\mathrm{G}_{0} / \mathrm{G}_{1}$ phase decreases, and this, in turn, reduces the number of cells in the $\mathrm{S}$ phase.

We next examined whether cell death results from mitotic arrest in PC3 cells. The results showed that the tested compounds caused greater cell death in PC3 cells than the

TABLE 5

Residues within $4 \AA$ of the binding pocket of 2l, epothilone, and paclitaxel

\begin{tabular}{lcc}
\hline Molecule & \multicolumn{1}{c}{ Common residues } & Uncommon residues \\
\hline Epothilone & $\beta$-tubulin residues D223, H226, L227, A230, & $\beta$-tubulin residues L214, L272, S274, R275, R281, L283, \\
& F269, P271, T273, L360, & Y280, Q278, Q279, G276 \\
$\mathbf{2 l}$ & & $\beta$-tubulin residues L214, L216, L272, S274, R275, P357, \\
Paclitaxel & $\mathbf{R 3 5 8}$ \\
\hline
\end{tabular}




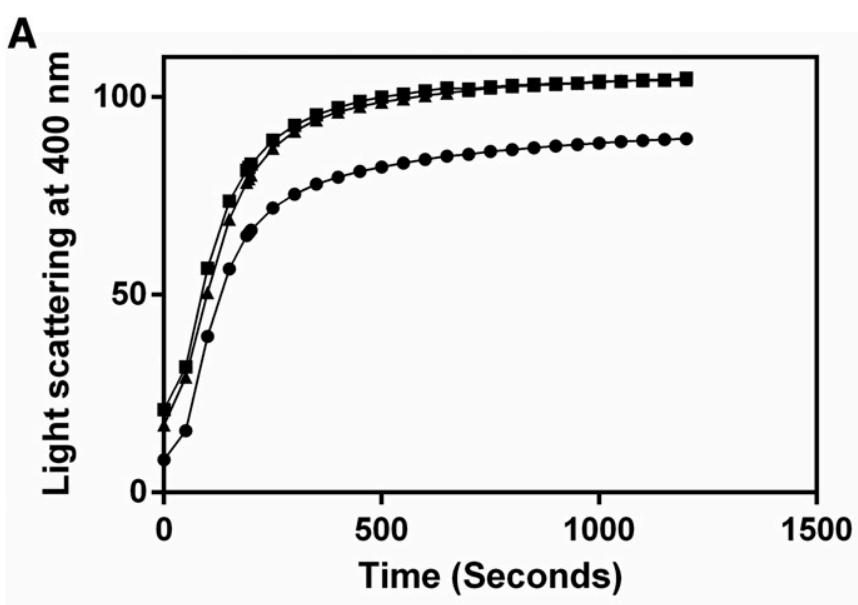

B

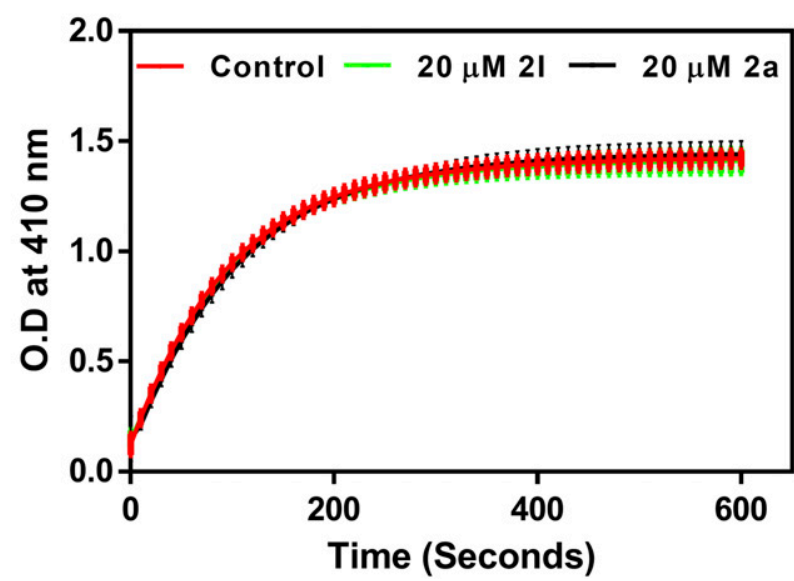

Fig. 14. The specificity of $\mathbf{2 a}$ and 21. (A) Polymerization of $s p n \mathrm{FtsZ}$ in the absence (-) and presence of $20 \mu \mathrm{M} \mathbf{2 a}(\mathbf{\Delta})$ and $2 \mathbf{l}(\boldsymbol{\bullet})$. (B) Activity of alkaline phosphatase in the presence and absence of $20 \mu \mathrm{M}$ of $\mathbf{2 a}$ and $\mathbf{2 l}$.

control (Table 3, Table 4; Supplemental Fig. 5). Analog $2 \mathbf{a}$ had the least effect on PC3 cells 72 hours after removal, despite showing $\mathrm{G}_{2} / \mathrm{M}$ arrest in the cell cycle analysis, indicating that cells treated with this analog may either have divided or remained in a senescing state. Treatment with analog 21 led to the greatest total percentage of dead PC3 cells. Analysis of the cell cycle in cells treated with analog $2 \mathbf{l}$ showed that this compound resulted in the greatest percentage of cells in the $\mathrm{G}_{2} / \mathrm{M}$ phase, indicating that the arrested cells undergo significant mitotic death.

There are three possible main outcomes from drug-mediated mitotic arrest upon drug removal (Yamada and Gorbsky, 2006): the cells divide (they may recover, leading to normal cell division or divide with abnormalities in the genome); the cells may remain in a senescent state, in which they are metabolically active but do not undergo further cell division; or cell death may be triggered, either by necrosis or apoptosis.

3,5-Bis(styryl)pyrazole 21 inhibited the polymerization of purified tubulin (Fig. 5), inhibiting both the rate and extent of tubulin assembly, as monitored by light scattering and sedimentation assay. Extensive testing of the effects of these pyrazoles on tubulin and microtubules showed that $2 \mathbf{l}$ binds to tubulin tightly with a $\mathrm{K}_{\mathrm{d}}$ of $0.4 \pm 0.1 \mu \mathrm{M}$ and inhibits the assembly of purified tubulin with no effect on the assembly of
FtsZ, a bacterial homolog of tubulin that shows the specific binding of $\mathbf{2 l}$ to tubulin only. Treatment with both pyrazoles 2a and $\mathbf{2 l}$ caused depolymerization of the microtubules in PC3 and HeLa cells. We also found that, although $\mathbf{2 l}$ depolymerizes microtubules, it shares its binding site on tubulin with paclitaxel. Paclitaxel is a known microtubule polymerizing agent, and paclitaxel site binders generally stabilize microtubules; however, few tubulin-binding small molecules, such as estramustine (Laing et al., 1997) and griseofulvin (Rathinasamy et al., 2010), are reported to share their binding sites with paclitaxel but to destabilize microtubules. In summary, we have identified a potential lead that could be the basis for future optimization in the search for novel agents for the treatment of CRPC. Both pyrazoles exert similar effects on HeLa cells (Supplemental Fig. 9), $\mathrm{GI}_{50} \mathrm{~s}$ of $2.6 \pm 1.2 \mu \mathrm{M}(\mathbf{2 a})$ and $2.4 \pm 0.5 \mu \mathrm{M}(\mathbf{2 l})$, through their interactions with tubulin and the depolymerization of microtubules in cells.

\section{Acknowledgments}

We thank Drs. Donna Lai and Sheng Hua at the Molecular Biology Facility, Bosch Institute for their technical support. We also thank Central Facility and Center for Research in Nanotechnology and Science (CRNTS), Indian Institute of Technology Bombay for kindly providing a spinning disc confocal microscope and fluorescenceactivated cell sorting facility.

\section{Authorship Contributions}

Participated in research design: Liao, Kumari, Narlawar, Vignarajan, Hibbs, Panda, Groundwater.

Conducted experiments: Liao, Kumari, Narlawar.

Contributed new reagents or tools: Liao, Kumari, Narlawar.

Performed data analysis: Liao, Kumari, Vignarajan, Hibbs, Panda, Groundwater.

Wrote or contributed to the writing of the manuscript: Liao, Kumari, Hibbs, Panda, Groundwater.

\section{References}

Abouelfadel Z and Crawford ED (2008) Leuprorelin depot injection: patient considerations in the management of prostatic cancer. Ther Clin Risk Manag 4:513-526.

Amolins MW, Peterson LB, and Blagg BSJ (2009) Synthesis and evaluation of electron-rich curcumin analogues. Bioorg Med Chem 17:360-367.

Bhattacharyya B, Kapoor S, and Panda D (2010) Fluorescence spectroscopic methods to analyze drug-tubulin interactions, in Microtubules, in Vitro: Microtubules, in Vitro (Wilson L and Correia JJ eds) pp 301-329, Elsevier Academic Press Inc, San Diego, CA.

Crawford ED, Eisenberger MA, McLeod DG, Spaulding JT, Benson R, Dorr FA, Blumenstein BA, Davis MA, and Goodman PJ (1989) A controlled trial of leuprolide with and without flutamide in prostatic carcinoma. N Engl J Med 321 $419-424$.

DeLano WL (2002) The PyMOL Molecular Graphics System, Version 1.1, Schrödinger LLC, New York, NY

Derenne A, Gasper R, and Goormaghtigh E (2010) Monitoring of metabolism perturbation in prostate PC-3 cancer cells by sub-lethal concentrations of methotrexate. J Spectrosc 24:55-60.

Dhaked HPS, Ray S, Battaje RR, Banerjee A, and Panda D (2019) Regulation of Streptococcus pneumoniae FtsZ assembly by divalent cations: paradoxical effects of $\mathrm{Ca} 2+$ on the nucleation and bundling of FtsZ polymers. FEBS J 286:3629-3646.

Feldman BJ and Feldman D (2001) The development of androgen-independent prostate cancer. Nat Rev Cancer 1:34-45.

Fuchs JR, Pandit B, Bhasin D, Etter JP, Regan N, Abdelhamid D, Li C, Lin J, and Li P-K (2009) Structure-activity relationship studies of curcumin analogues. Bioorg Med Chem Lett 19:2065-2069.

Garnick MB (1997) Hormonal therapy in the management of prostate cancer: from Huggins to the present. Urology 49(3A Suppl):5-15.

Gordon ON, Luis PB, Sintim HO, and Schneider C (2015) Unraveling curcumin degradation: autoxidation proceeds through spiroepoxide and vinylether intermediates en route to the main bicyclopentadione. J Biol Chem 290:4817-4828.

Groundwater PW, Narlawar R, Liao VWY, Bhattacharya A, Srivastava S, Kunal K, Doddareddy M, Oza PM, Mamidi R, Marrs ECL, et al. (2017) A carbocyclic curcumin inhibits proliferation of gram-positive bacteria by targeting FtsZ. Biochemistry 56:514-524.

Hire RR, Srivastava S, Davis MB, Kumar Konreddy A, and Panda D (2017) Antiproliferative activity of crocin involves targeting of microtubules in breast cancer cells. Sci Rep 7:44984. 
Hura N, Naaz A, Prassanawar SS, Guchhait SK, and Panda D (2018) Drug-clinical agent molecular hybrid: synthesis of diaryl(trifluoromethyl)pyrazoles as tubulin targeting anticancer agents. ACS Omega 3:1955-1969.

Jaghoori MM, Bleijlevens B, and Olabarriaga SD (2016) 1001 ways to run AutoDock Vina for virtual screening. J Comput Aided Mol Design 30:237-249.

Jayaprakasha GK, Jagan Mohan Rao L, and Sakariah KK (2002) Improved HPLC method for the determination of curcumin, demethoxycurcumin, and bisdemethoxycurcumin. J Agric Food Chem 50:3668-3672.

Karantanos T, Corn PG, and Thompson TC (2013) Prostate cancer progression after androgen deprivation therapy: mechanisms of castrate resistance and novel therapeutic approaches. Oncogene 32:5501-5511.

Laing N, Dahllöf B, Hartley-Asp B, Ranganathan S, and Tew KD (1997) Interaction of Estramustine with Tubulin Isotypes. Biochemistry 36:871-878.

Lin W and Chen T (2013) A vinblastine fluorescent probe for pregnane X receptor in a time-resolved fluorescence resonance energy transfer assay. Anal Biochem 443 $252-260$.

Luo JX, Ding W, Zhang YQ, Yang ZG, Li Y, and Ding LJ (2013) Semisynthesis and acaricidal activities of isoxazole and pyrazole derivatives of a natural product bisdemethoxycurcumin. J Pestic Sci 38:214-219.

Marques SM, Enyedy ÉA, Supuran CT, Krupenko NI, Krupenko SA, and Santos MA (2010) Pteridine-sulfonamide conjugates as dual inhibitors of carbonic anhydrases and dihydrofolate reductase with potential antitumor activity. Bioorg Med Chem 18:5081-5089.

Mayadevi M, Sherin DR, Keerthi VS, Rajasekharan KN, and Omkumar RV (2012) Curcumin is an inhibitor of calcium/calmodulin dependent protein kinase II. Bioorg Med Chem 20:6040-6047.

Mosmann T (1983) Rapid colorimetric assay for cellular growth and survival: application to proliferation and cytotoxicity assays. J Immunol Methods 65:55-63.

Mukhtar E, Adhami VM, and Mukhtar H (2014) Targeting microtubules by natural agents for cancer therapy. Mol Cancer Ther 13:275-284.

Panda D, Rathinasamy K, Santra MK, and Wilson L (2005) Kinetic suppression of microtubule dynamic instability by griseofulvin: implications for its possible use in the treatment of cancer. Proc Natl Acad Sci USA 102:9878-9883.

Pettersen EF, Goddard TD, Huang CC, Couch GS, Greenblatt DM, Meng EC, and Ferrin TE (2004) UCSF Chimera--a visualization system for exploratory research and analysis. J Comput Chem 25:1605-1612.

Pulukuri SM, Gondi CS, Lakka SS, Jutla A, Estes N, Gujrati M, and Rao JS (2005) RNA interference-directed knockdown of urokinase plasminogen activator and urokinase plasminogen activator receptor inhibits prostate cancer cell invasion, survival, and tumorigenicity in vivo. J Biol Chem 280:36529-36540.

Ranade AR, Higgins L, Markowski TW, Glaser N, Kashin D, Bai R, Hong KH, Hamel E, Höfle G, and Georg GI (2016) Characterizing the epothilone binding site on $\beta$-tubulin by photoaffinity labeling: identification of $\beta$-tubulin peptides TARGSQQY and TSRGSQQY as targets of an epothilone photoprobe for polymerized tubulin. J Med Chem 59:3499-3514

Rane JS, Bhaumik P, and Panda D (2017) Curcumin inhibits tau aggregation and disintegrates preformed tau filaments in vitro. J Alzheimers Dis 60:999-1014.
Rathinasamy K, Jindal B, Asthana J, Singh P, Balaji PV, and Panda D (2010) Griseofulvin stabilizes microtubule dynamics, activates p53 and inhibits the proliferation of MCF-7 cells synergistically with vinblastine. BMC Cancer 10:213, doi: 10.1186/1471-2407-10-213.

Sawant AV, Srivastava S, Prassanawar SS, Bhattacharyya B, and Panda D (2019) Crocin, a carotenoid, suppresses spindle microtubule dynamics and activates the mitotic checkpoint by binding to tubulin. Biochem Pharmacol 163:32-45.

Schmitt J, Noble A, Otsuka M, Berry P, Maitland NJ, and Rumsby MG (2014) Phorbol ester stimulates ethanolamine release from the metastatic basal prostate cancer cell line PC3 but not from prostate epithelial cell lines LNCaP and P4E6. Br $J$ Cancer 111:1646-1656.

Schüttelkopf AW and van Aalten DM (2004) PRODRG: a tool for high-throughput crystallography of protein-ligand complexes. Acta Crystallogr D Biol Crystallogr 60:1355-1363.

Serova M, Bieche I, Sablin MP, Pronk GJ, Vidaud M, Cvitkovic E, Faivre S, and Raymond E (2011) Single agent and combination studies of pralatrexate and molecular correlates of sensitivity. Br J Cancer 104:272-280.

Snyder JP, Nettles JH, Cornett B, Downing KH, and Nogales E (2001) The binding conformation of Taxol in $\beta$-tubulin: a model based on electron crystallographic density. Proc Natl Acad Sci USA 98:5312-5316.

Taplin ME and Balk SP (2004) Androgen receptor: a key molecule in the progression of prostate cancer to hormone independence. J Cell Biochem 91:483-490.

Todd A, Groundwater PW, and Gill JH (2018) Anticancer Therapeutics: From Drug Discovery to Clinical Applications, John Wiley \& Sons Ltd., Chichester, UK.

Tønnesen HH and Karlsen J (1985) Studies on curcumin and curcuminoids. VI. Kinetics of curcumin degradation in aqueous solution. Z Lebensm Unters Forsch 180:402-404.

Torne SJ, Ansari KA, Vavia PR, Trotta F, and Cavalli R (2010) Enhanced oral paclitaxel bioavailability afteradministration of paclitaxel-loaded nanosponges. Drug Delivery 17:419-425, doi: 10.3109/10717541003777233.

Trott O and Olson AJ (2010) AutoDock Vina: improving the speed and accuracy of docking with a new scoring function, efficient optimization, and multithreading. J Comput Chem 31:455-461.

Vichai V and Kirtikara K (2006) Sulforhodamine B colorimetric assay for cytotoxicity screening. Nat Protoc 1:1112-1116.

Yadava U, Gupta H, and Roychoudhury M (2015) Stabilization of microtubules by taxane diterpenoids: insight from docking and MD simulations. J Biol Phys 41 117-133.

Yamada HY and Gorbsky GJ (2006) Spindle checkpoint function and cellular sensitivity to antimitotic drugs. Mol Cancer Ther 5:2963-2969.

Address correspondence to: Paul W. Groundwater, Sydney Pharmacy School, Faculty of Medicine and Health, The University of Sydney, Sydney, NSW 2006, Australia. E-mail: paul.groundwater@sydney.edu.au; or Dulal Panda, Department of Biosciences and Bioengineering, Indian Institute of Technology Bombay, Mumbai 400076, India. E-mail: panda@iitb.ac.in 